\title{
\#USGS
}

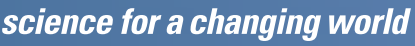

Prepared in cooperation with Southwestern Energy Company

\section{Simulated Effects of Existing and Proposed Surface-Water Impoundments and Gas-Well Pads on Streamflow and Suspended Sediment in the Cypress Creek Watershed, Arkansas}

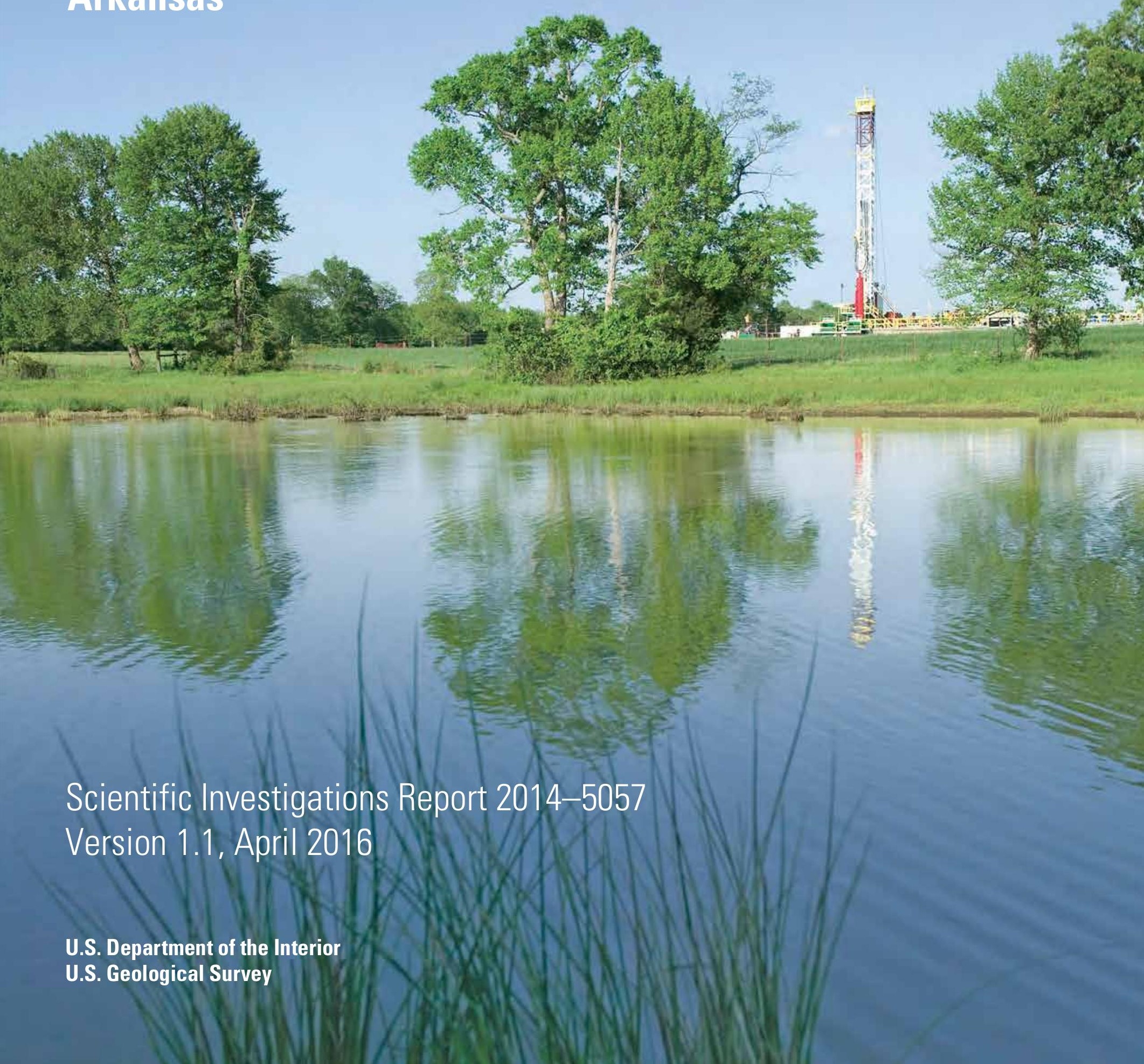


Cover: Surface-water impoundment located in the Fayetteville Shale, central Arkansas (photograph provided by Southwestern Energy Company) 


\section{Simulated Effects of Existing and Proposed Surface-Water Impoundments and Gas-Well Pads on Streamflow and Suspended Sediment in the Cypress Creek Watershed, Arkansas}

By Rheannon M. Hart

Prepared in cooperation with Southwestern Energy Company

Scientific Investigations Report 2014-5057

Version 1.1, April 2016 


\title{
U.S. Department of the Interior SALLY JEWELL, Secretary
}

\section{U.S. Geological Survey Suzette M. Kimball, Acting Director}

\author{
U.S. Geological Survey, Reston, Virginia: 2014 \\ First release: 2014 \\ Revised: April 2016 (ver 1.1)
}

\begin{abstract}
For more information on the USGS - the Federal source for science about the Earth, its natural and living resources, natural hazards, and the environment, visit http://www.usgs.gov or call 1-888-ASK-USGS. For an overview of USGS information products, including maps, imagery, and publications, visit http://www.usgs.gov/pubprod

To order this and other USGS information products, visit http://store.usgs.gov
\end{abstract}

Any use of trade, firm, or product names is for descriptive purposes only and does not imply endorsement by the U.S. Government.

Although this information product, for the most part, is in the public domain, it also may contain copyrighted materials as noted in the text. Permission to reproduce copyrighted items must be secured from the copyright owner.

Suggested citation:

Hart, R.M., 2014, Simulated effects of existing and proposed surface-water impoundments and gas-well pads on streamflow and suspended sediment in the Cypress Creek watershed, Arkansas (ver. 1.1, April 2016): U.S. Geological Survey Scientific Investigations Report 2014-5057, 36 p., http://dx.doi.org/10.3133/sir20145057.

ISSN -2328-0328 (online) 


\section{Contents}

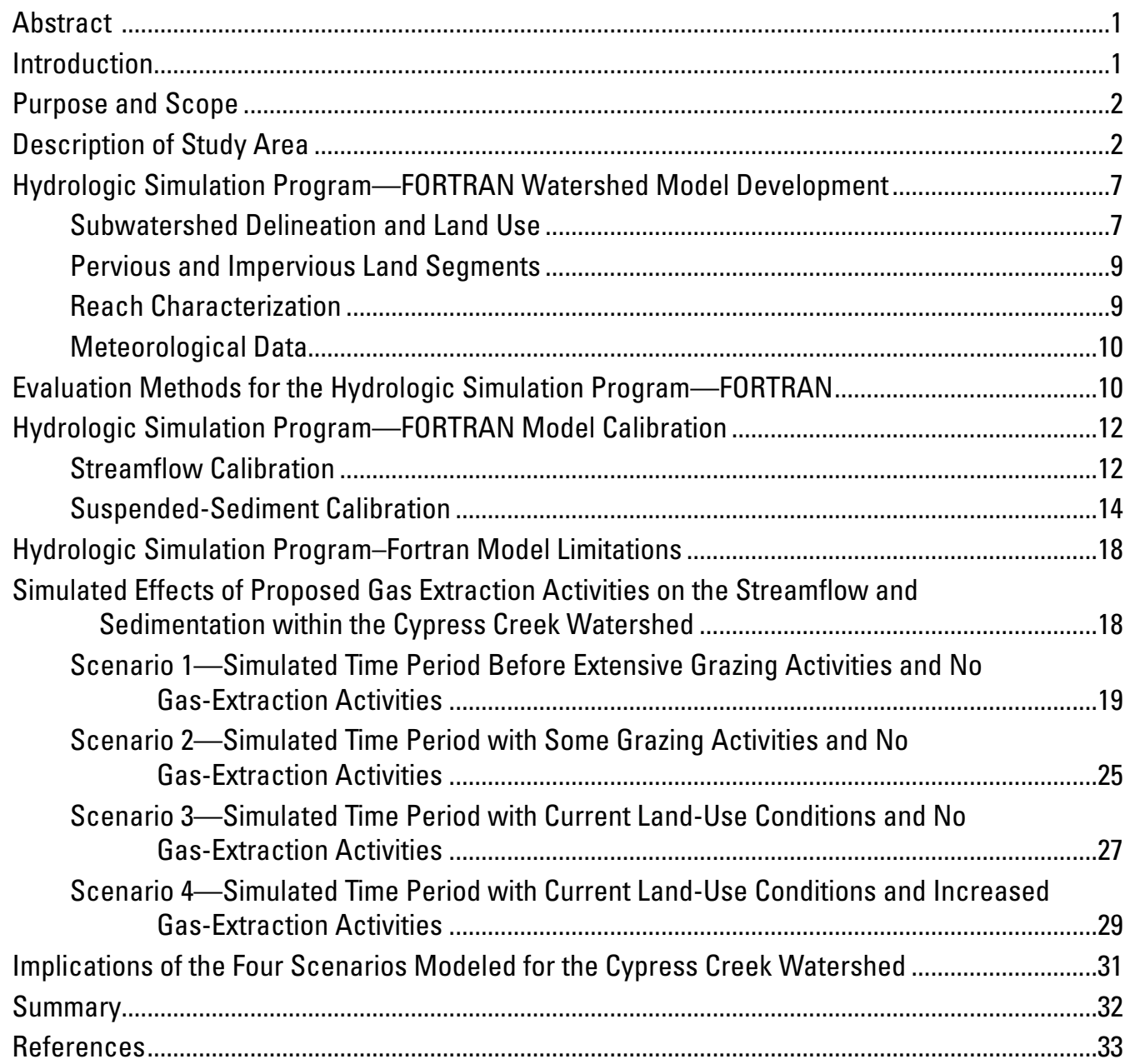




\section{Figures}

1. Map showing location of study area, Cypress Creek watershed, Arkansas

2. Map showing soil types within the study area, Cypress Creek watershed, Arkansas

3. Map showing the 2006 land use and land cover with 2013 gas-well pads, pipelines, and surface-water impoundments, location of a streamflow-gaging and a water-quality sampling station, and withdrawal points within the study area, Cypress Creek watershed, Arkansas

4. Map showing locations of the subwatersheds and reaches within the Cypress Creek watershed used for the Hydrologic Simulation Program-FORTRAN model.........8

5. Map showing location of the Next Generation Radar (NEXRAD) grid, Cypress Creek watershed, Arkansas

6. Graph showing simulated and measured daily mean streamflow at the Cypress Creek gage in the Cypress Creek watershed.

7. Graph showing exceedance probability of simulated and measured daily mean streamflow at selected inflow stations in the Cypress Creek watershed.

8. Graph showing simulated and measured suspended-sediment concentrations at Cypress Creek near Birdtown.

9. Map showing land-use types used in scenario 1, a time period before extensive-grazing activities and no gas-extraction activities in the Cypress Creek watershed, Arkansas.

10. Graph showing comparison of total streamflow volume for the calibration period (July 8, 2009-September 2012) between the current-conditions simulation and scenario simulations for the Cypress Creek watershed

11. Graph showing comparison of yearly suspended-sediment load between the current-conditions simulation and scenario simulations for the Cypress Creek watershed

12. Map showing land-use types used in scenario 2, a time period with some grazing but before any gas-extraction activities in the Cypress Creek watershed, Arkansas

13. Map showing land-use types used in scenario 3, a time period with current conditions but without any gas-extraction activities in the Cypress Creek watershed, Arkansas

14. Map showing potential future conditions of increased gas-extraction activities for scenario 4 in the Cypress Creek watershed, Arkansas ..... 


\section{Tables}

1. Land-use types and characteristics designated for pervious and impervious areas within subwatersheds, Cypress Creek watershed, Arkansas ................................6

2. Withdrawals and surface-water impoundment volumes for use in the Cypress Creek watershed model...

3. Summary of calibrated values for selected hydrology parameters for the Hydrological Simulation Program-FORTRAN model of the Cypress Creek watershed.

4. Hydrological Simulation Program-FORTRAN streamflow calibration results for the Cypress Creek watershed

5. Land-use loading rates for the Hydrological Simulation Program-FORTRAN model of the Cypress Creek watershed.

6. Summary of calibrated values for suspended-sediment parameters for the Hydrological Simulation Program-FORTRAN model of the Cypress Creek watershed

7. Measured and simulated suspended-sediment concentrations and suspended-sediment calibration statistics for the Hydrological Simulation Program-FORTRAN model at Cypress Creek near Birdtown

8. Summary of July 8, 2009-September 30, 2012 simulation results for land-use change scenarios on Brewer Lake in the Cypress Creek watershed

\section{Conversion Factors}

\begin{tabular}{|c|c|c|}
\hline Multiply & By & To obtain \\
\hline \multicolumn{3}{|c|}{ Length } \\
\hline inch (in.) & 2.54 & centimeter $(\mathrm{cm})$ \\
\hline inch (in.) & 25.4 & millimeter $(\mathrm{mm})$ \\
\hline foot (ft) & 0.3048 & meter $(\mathrm{m})$ \\
\hline mile (mi) & 1.609 & kilometer (km) \\
\hline yard (yd) & 0.9144 & meter $(\mathrm{m})$ \\
\hline \multicolumn{3}{|c|}{ Area } \\
\hline acre & 4,047 & square meter $\left(\mathrm{m}^{2}\right)$ \\
\hline square mile $\left(\mathrm{mi}^{2}\right)$ & 2.590 & square kilometer $\left(\mathrm{km}^{2}\right)$ \\
\hline \multicolumn{3}{|c|}{ Volume } \\
\hline million gallons (Mgal) & 3,785 & cubic meter $\left(\mathrm{m}^{3}\right)$ \\
\hline acre-foot (acre-ft) & 1,233 & cubic meter $\left(\mathrm{m}^{3}\right)$ \\
\hline \multicolumn{3}{|c|}{ Flow rate } \\
\hline cubic foot per second $\left(\mathrm{ft}^{3} / \mathrm{s}\right)$ & 0.02832 & cubic meter per second $\left(\mathrm{m}^{3} / \mathrm{s}\right)$ \\
\hline million gallons per day (Mgal/d) & 0.04381 & cubic meter per second $\left(\mathrm{m}^{3} / \mathrm{s}\right)$ \\
\hline \multicolumn{3}{|c|}{ Mass } \\
\hline ton per day (ton/d) & 0.9072 & metric ton per day \\
\hline ton per day (ton/d) & 0.9072 & megagram per day $(\mathrm{Mg} / \mathrm{d})$ \\
\hline \multicolumn{3}{|c|}{ Application rate } \\
\hline $\begin{array}{l}\text { pounds per acre per year } \\
{[(\mathrm{lb} / \mathrm{acre}) / \mathrm{yr}]}\end{array}$ & 1.121 & $\begin{array}{l}\text { kilograms per hectare per year } \\
{[(\mathrm{kg} / \mathrm{ha}) / \mathrm{yr}]}\end{array}$ \\
\hline
\end{tabular}

Vertical coordinate information is referenced to the National Geodetic Vertical Datum of 1929 (NGVD 1929) 



\title{
Simulated Effects of Existing and Proposed Surface-Water Impoundments and Gas-Well Pads on Streamflow and Suspended Sediment in the Cypress Creek Watershed, Arkansas
}

\author{
By Rheannon M. Hart
}

\section{Abstract}

Cypress Creek is located in central Arkansas and is the main tributary to Brewer Lake, which serves as the primary water supply for Conway, Arkansas, and the surrounding areas. A model of the Cypress Creek watershed was developed and calibrated in cooperation with Southwestern Energy Company using detailed precipitation, streamflow, and discrete suspended-sediment data collected from 2009 through 2012. These data were used with a Hydrologic Simulation Program-FORTRAN model to address different potential gas-extraction activities within the watershed.

The calibrated Hydrologic Simulation ProgramFORTRAN model was used to simulate four land-use scenarios and examine the potential effects of these landuse changes on the streamflow and water quality within the Cypress Creek watershed. These simulated scenarios included (1) the conversion of all nonforested land to forest, representing a time period before extensive grazing activities and no gas-extraction activities; (2) a land-use change to that of 1949, representing a time period with some grazing activities and no gas-extraction activities; (3) a time period with current land-use conditions, but without any gas-extraction activities, that is, the exclusion of gas-well pads/pipelines, associated gravel roads, and surface-water impoundments; and (4) a time period with current landuse conditions, but with increased gas-extraction activities (for example, increased gas-well pad and surface-water impoundment activities) to represent a possible future natural gas full-development condition for the area.

A current-conditions simulation also was built and calibrated and represents the current conditions (2013) within the watershed. This simulation was used as the comparison basis for the four land-use scenarios described above. The current-conditions simulation used the 2006 land-use conditions, which consisted primarily of forest and pasture, as well as the current (2013) 35 gas-well pads and pipelines and 6 surface-water impoundments, which account for approximately 1.6 percent of the land use. Simulating a time period before extensive-grazing activities and no gas-extraction activities for scenario 1 resulted in a decrease in suspended-sediment loads and volume of streamflow within the Cypress Creek watershed compared to the currentconditions simulation. Simulating a time period before any gas-extraction activities but with some grazing activities for scenario 2 also resulted in a decrease in suspended-sediment loads and volume of streamflow within the Cypress Creek watershed. Simulating current conditions, but without any natural gas-pad land use or related activities (including pipelines and associated gravel roads), for scenario 3 resulted in mostly unchanged suspended-sediment loads and volume of streamflow within the Cypress Creek watershed, as compared to the current-conditions simulation. Finally, simulating potential future conditions of increased gas-well pad and surface-water impoundment activities for scenario 4 resulted in a decrease (compared to the current-conditions simulation) in suspended-sediment loads and a slight increase of volume of streamflow within the Cypress Creek watershed.

The Arkansas Natural Resources Commission and the Arkansas Department of Environmental Quality list suspended sediment from "poor pastures" as a primary source of nonpoint-source pollution in north-central Arkansas, but unpaved (gravel) roads are another important source of suspended sediment. Because of the high sediment-loading rates associated with gravel roads and the large amount of pasture within the watershed, the factors most responsible for suspended sediment within the Cypress Creek watershed are likely associated more with the pastureland and gravel roads, than factors associated with gas-well pads/pipelines.

\section{Introduction}

Brewer Lake, located in central Arkansas, is an impoundment on Cypress Creek and serves as the city of Conway's major drinking-water source. Brewer Lake was constructed in the early 1980 s and was designed to provide 16.75 million gallons per day (Mgal/d) of water to the city of Conway and the surrounding area that is serviced by the Conway County Regional Water District (U.S. Army 
Corps of Engineers, 2002). The Cypress Creek watershed, defined as the catchment area upstream from the Brewer Lake spillway, has experienced a notable increase in gasextraction activities in the last 6 years (Southwestern Energy Co., written commun., 2013). Concerns about the impacts that gas development could have on the drinking-water source have been raised, and the necessity to understand the effects of additional increases in gas activities needs to be addressed. Using streamflow data (collected in cooperation with Conway Corporation) and suspended-sediment data (collected in cooperation with Southwestern Energy Company [SWN]), the U.S. Geological Survey (USGS), in cooperation with SWN, developed and calibrated a model simulating streamflow and suspended sediment in the Cypress Creek watershed from July 8, 2009, through September 30, 2012, and has applied the model to evaluate four scenarios related to potential gasextraction activities within the watershed.

\section{Purpose and Scope}

The purpose of this report is to present the development and findings of a model used to simulate the effects of land-use changes resulting from gas-extraction activities on streamflow and sediment load within the Cypress Creek watershed. Descriptions are provided for the development and results of a Hydrologic Simulation Program - FORTRAN (HSPF) (Bicknell and others, 2001) watershed model (hereafter referred to as the "HSPF model") of the Cypress Creek watershed. The HSPF model input data are described, followed by a discussion of the development, calibration, and application of the model. The HSPF model was developed to simulate streamflow and suspended sediment using data collected from July 8, 2009, through September 30, 2012. The calibrated HSPF model was used to simulate four scenarios, which represent a range of potential generalized land-use changes that could result from potential gas-extraction activities in the watershed; evaluation was conducted of possible effects of anthropogenic (human-induced) activities in the Cypress Creek watershed. The calibrated HSPF model, however, does not capture effects at small, localized scales, for example, the sediment load in a stream immediately downstream from a gas-well pad or a pipeline crossing.

\section{Description of Study Area}

Brewer Lake (fig. 1) is located in central Arkansas, 10 miles (mi) northwest of the city of Conway, and serves as the city's primary water supply. Brewer Lake was formed by the impoundment of Cypress Creek, which was completed September 1982, and comprises an area of approximately 1,165 acres (1.8 square miles[ $\left.\mathrm{mi}^{2}\right]$ ) (Conway Corporation, 2012). The lake shoreline is approximately $13 \mathrm{mi}$ and the mean depth is approximately 20.2 feet (ft). Brewer Lake contains approximately 23,500 acre-feet (acre-ft) of water when the water surface is at the spillway $(339.5 \mathrm{ft}$ above National Geodetic Vertical Datum of 1929 [NGVD 29]) (Conway Corporation, 2012) and is used primarily for drinking water, but also for recreation and fish and wildlife habitat. The drainage area of Cypress Creek watershed, that is upstream from the Brewer Lake spillway located near USGS water-quality sampling station 07261110 , is approximately $36 \mathrm{mi}^{2}$, including the reservoir surface (Conway Corporation, 2012). Cypress Creek is approximately $22.3 \mathrm{mi}$ long from its headwaters to the confluence with the larger Cadron Creek (fig. 1). Additionally, Brewer Lake is not included in the study area (that is, it is not explicitly modeled within the HSPF Cypress Creek watershed model). The study area ends at the mouth of Cypress Creek and other smaller tributaries flowing into Brewer Lake.

The Cypress Creek watershed lies entirely within the Arkansas Valley physiographic section (Fenneman and Johnson, 1946; fig. 1). The Arkansas Valley is the northern extent of the Ouachita Mountains in Arkansas (Arkansas Geological Survey, 2012). The Arkansas Valley consists of Pennsylvanian sedimentary rocks that have been compressed into well-developed east-west trending open folds (anticlines and synclines) and faults (Arkansas Geological Survey, 2012).

The soils in the watershed consist primarily of the Linker and Mountainburg series (U.S. Department of Agriculture, 2012b; fig. 2). The Linker series is described as moderately deep, well-drained, moderately permeable soils that formed in loamy residuum weathered from sandstone. The Mountainburg series is described as shallow, well-drained, moderate to rapid permeable soils that formed in residuum of sandstone. Slopes are dominantly 1 to 15 percent but range upward to 30 percent (U.S. Department of Agriculture, 2012b).

According to the 2006 land-use data, 53.0 percent of the land-use area within the Cypress Creek watershed is forest (deciduous, evergreen, and mixed), 34.9 percent pasture, 4.1 percent roads (including both gravel and paved), 0.9 percent shrub, 0.4 percent urban, and 5.1 percent water, including Brewer Lake (Arkansas Natural Resources Commission and University of Arkansas: Center for Advanced Spatial Technologies, 2009). The remaining land-use area (1.6 percent) is either gas-well pads/pipelines or surface-water impoundments (fig. 3, table 1). Surface-water impoundments were constructed to supply water for gas extraction activities. Currently (2013), there are 12 permitted no-discharge facilities that exist in the watershed. These include six confinedanimal feeding operations involving swine or dairy cattle (Arkansas Department of Environmental Quality, 2008), although chicken houses also have been observed within the watershed. Additionally, SWN provided permit information for four withdrawals located on Cypress Creek, as well as six withdrawals on the six gas-well surface-water impoundments; these locations and water volumes were included in model development and are described in more detail in the "Hydrologic Simulation Program—FORTRAN Model Calibration" section. 


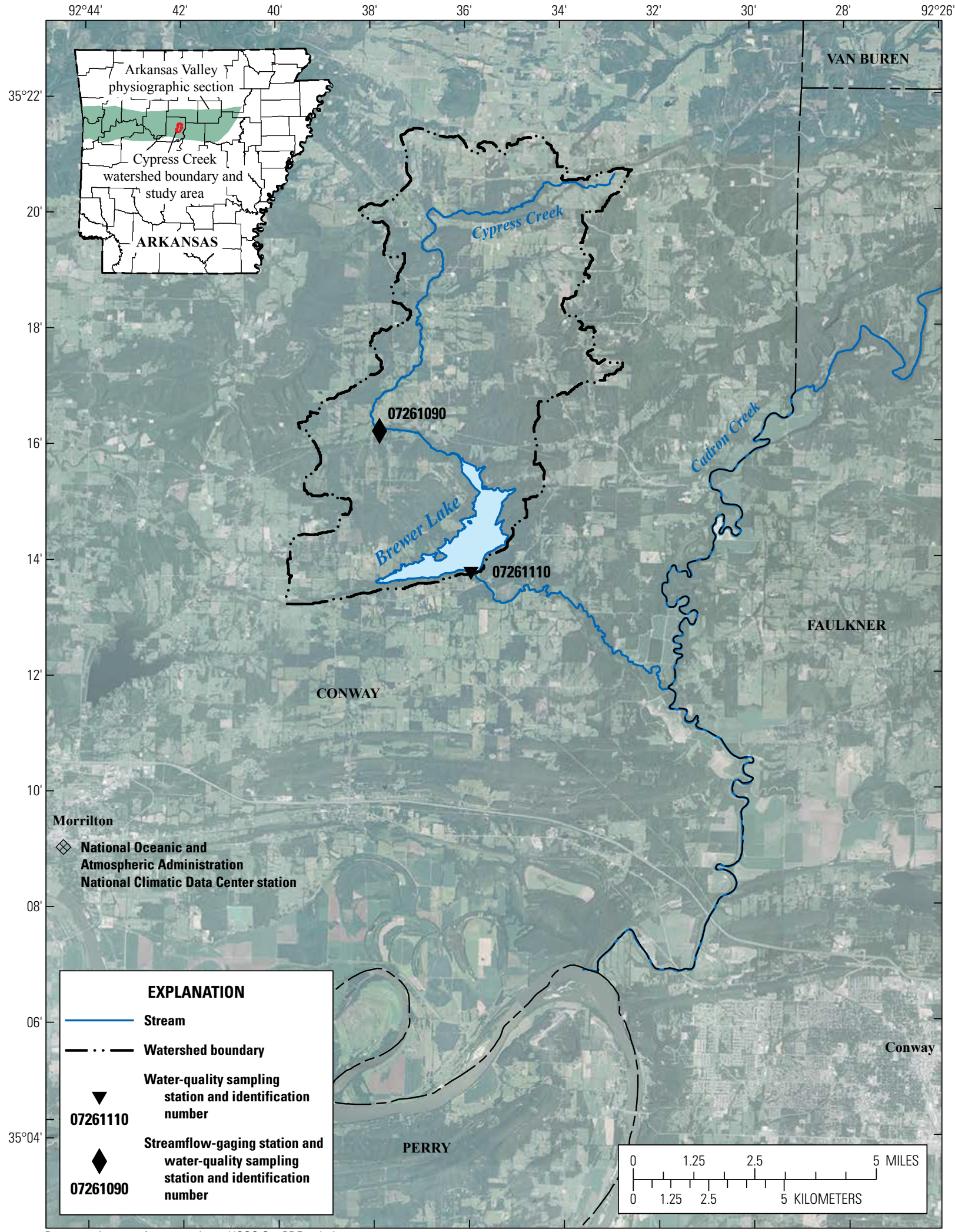

Base map imagery from 7.5 minute USGS GeoPDF orthoimagery.

Figure 1. Location of study area, Cypress Creek watershed, Arkansas. 


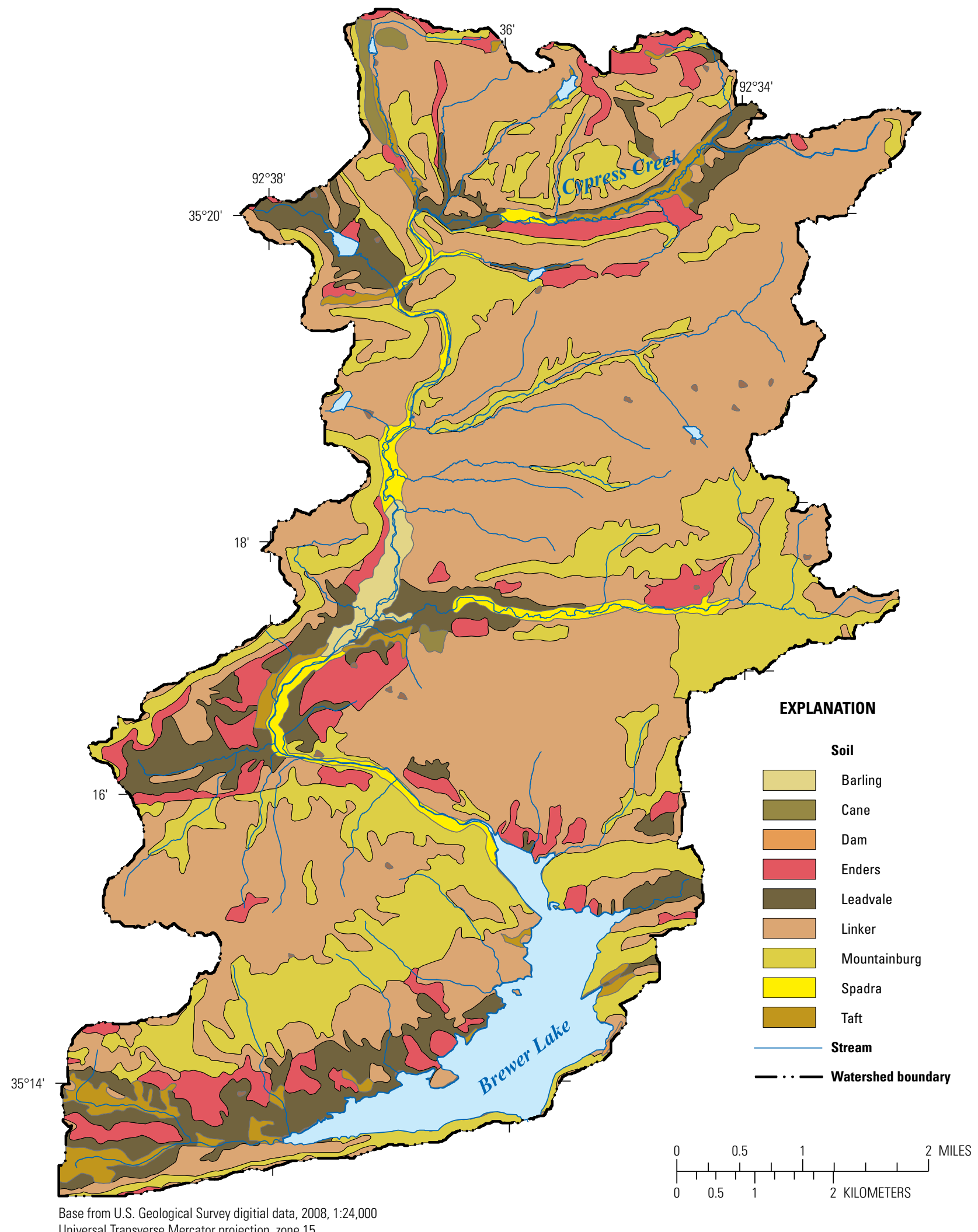

Figure 2. Soil types within the study area, Cypress Creek watershed, Arkansas. 


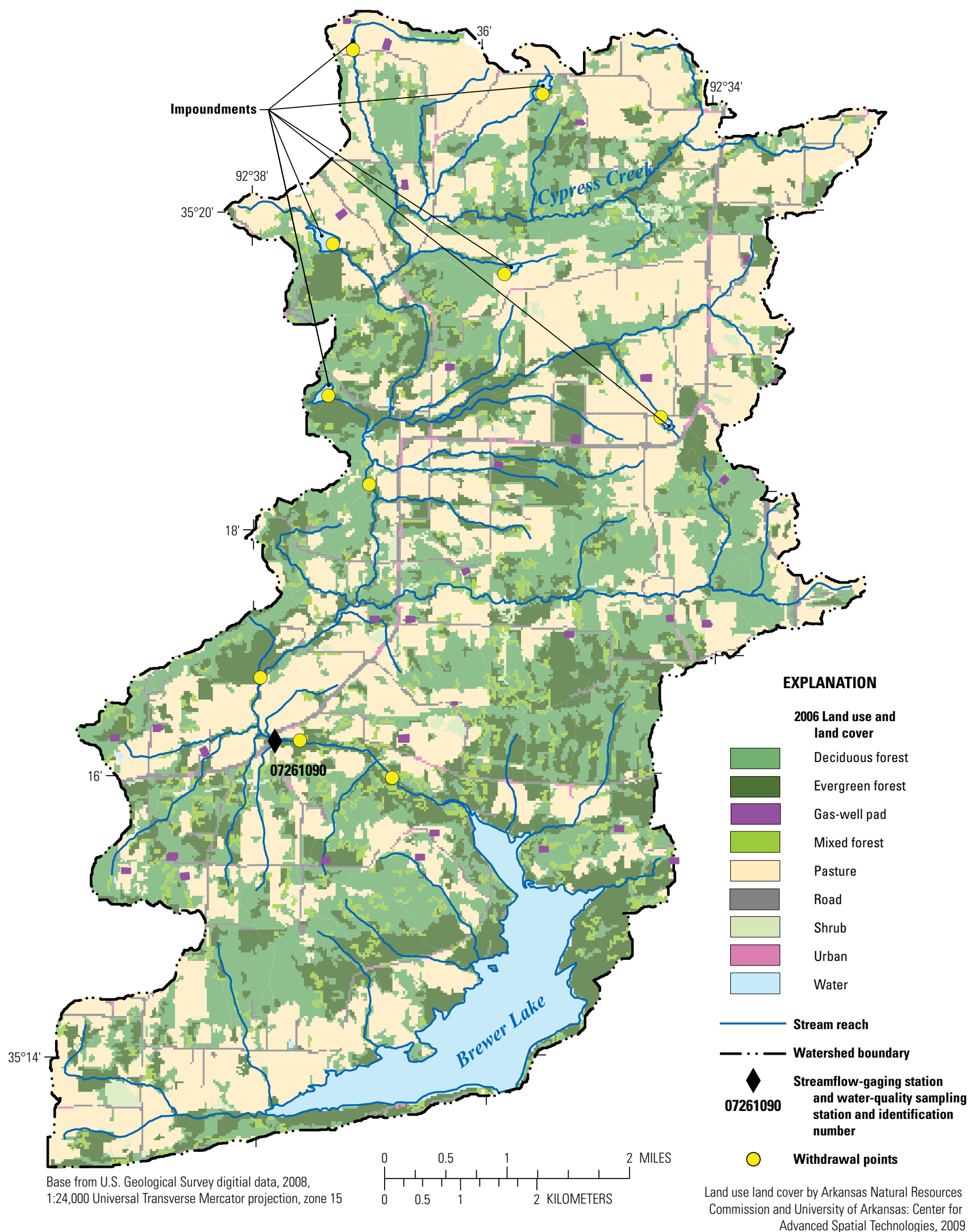

Figure 3. The 2006 land use and land cover with 2013 gas-well pads, pipelines, and surface-water impoundments, location of a streamflow-gaging and a water-quality sampling station, and withdrawal points within the study area, Cypress Creek watershed, Arkansas. 
Table 1. Land-use types and characteristics designated for pervious and impervious areas within subwatersheds, Cypress Creek watershed, Arkansas.

[Current conditions consist of the 2006 land-use conditions and the 2013 gas-well pads, pipelines, and surface-water impoundments. Percentage does not total to 100 percent because of rounding]

\begin{tabular}{|c|c|c|c|c|c|c|}
\hline \multirow[b]{2}{*}{ Land use } & \multirow[b]{2}{*}{$\begin{array}{c}\text { Current } \\
\text { conditions } \\
\text { total area } \\
\text { (square miles) }\end{array}$} & \multirow[b]{2}{*}{$\begin{array}{c}\text { Current } \\
\text { conditions } \\
\text { land-use } \\
\text { percentage }\end{array}$} & \multicolumn{4}{|c|}{ Land-use percentage } \\
\hline & & & $\begin{array}{l}\text { Time period before } \\
\text { extensive grazing } \\
\text { activities and no gas- } \\
\text { extraction activities } \\
\text { (scenario 1) }\end{array}$ & $\begin{array}{l}\text { Time period with } \\
\text { some grazing } \\
\text { activities and no gas- } \\
\text { extraction activities } \\
\text { (scenario 2) }\end{array}$ & $\begin{array}{l}\text { Time period with } \\
\text { current land-use } \\
\text { conditions and no gas- } \\
\text { extraction activities } \\
\text { (scenario } 3 \text { ) }\end{array}$ & $\begin{array}{l}\text { Time period with current } \\
\text { land-use conditions } \\
\text { and increased gas- } \\
\text { extraction activities } \\
\text { (scenario 4) }\end{array}$ \\
\hline Deciduous forest & 10.3 & 28.9 & 59.4 & 36.2 & 29.1 & 26.7 \\
\hline Evergreen forest & 7.0 & 19.6 & 40.6 & 39.8 & 20.0 & 18.8 \\
\hline Gas-well pads/pipelines & 0.5 & 1.4 & 0.0 & 0.0 & 0.0 & 6.9 \\
\hline Mixed forest & 1.6 & 4.5 & 0.0 & 0.0 & 4.5 & 4.4 \\
\hline Pasture & 12.5 & 34.9 & 0.0 & 22.4 & 36.0 & 31.4 \\
\hline Gravel roads & 1.5 & 4.1 & 0.0 & 1.5 & 4.0 & 4.4 \\
\hline Shrub & 0.3 & 0.9 & 0.0 & 0.0 & 0.9 & 1.0 \\
\hline Urban & 0.1 & 0.4 & 0.0 & 0.0 & 0.4 & 0.4 \\
\hline Surface-water impoundments & 0.1 & 0.2 & 0.0 & 0.0 & 0.0 & 1.0 \\
\hline Brewer Lake & 1.8 & 5.1 & 0.0 & 0.0 & 5.1 & 5.1 \\
\hline
\end{tabular}




\section{Hydrologic Simulation Program- FORTRAN Watershed Model Development}

Hydrologic Simulation Program-FORTRAN is a watershed model developed to simulate the hydrologic and associated water-quality processes on a specified time step for pervious and impervious land surfaces and in streams (Bicknell and others, 2001). HSPF model also is a semilumped-parameter model that simulates spatial variability by discretizing the watershed into hydrologically similar land units based on relative similarity of land use, soils, topography, and other hydrologic characteristics. A water budget is calculated by the HSPF model, where inflows equal outflows plus or minus change in storage for each time step. Within the HSPF model, some parameters are set equal to measured or default values; however, most parameters are adjusted during the calibration process. A complete description of the mathematical equations and model variables can be found in Bicknell and others (2001).

Numerous datasets are required in the development of a HSPF model. Datasets compiled for this study include National Elevation Dataset (NED) (U.S. Geological Survey, 2011) for use in delineating subwatersheds; the National Hydrography Dataset (NHD) (U.S. Geological Survey, 2012a) that includes all the stream reaches within the Cypress Creek watershed; the 2006 Arkansas land-use map (Arkansas Natural Resources Commission and University of Arkansas: Center for Advanced Spatial Technologies, 2009); the Soil Survey Geographic database for each county within the watershed (U.S. Department of Agriculture, 2012a,b); and Next-Generation Radar (NEXRAD) hourly precipitation data (National Oceanic and Atmospheric Administration, 2012a), as well as other meteorological data including air temperature. Air temperature was obtained from the National Oceanic and Atmospheric Administration, National Climatic Data Center Morrilton station located approximately $11 \mathrm{mi}$ southwest of the watershed (National Oceanic and Atmospheric Administration, 2012b) (fig. 1).

The USGS operates a continuous streamflow-gaging station and water-quality sampling station on Cypress Creek in north-central Arkansas. This streamflow-gaging station (fig. 3) was the only station used in the calibration process and is USGS station 07261090, Cypress Creek near Birdtown (hereafter referred to as Cypress Creek) (fig. 3). Continuous streamflow data were collected from Cypress Creek beginning on July 8,2009 . The streamgage was operated and streamflow was measured according to the methods described in Rantz and others (1982). Streamflow, in cubic feet per second $\left(\mathrm{ft}^{3} / \mathrm{s}\right)$, was computed every 15 minutes and averaged daily from 2009 through 2012 (and continues) at the site. All streamflow data described are available on the web at http://water.usgs.gov/ar/nwis. Water-quality samples, with corresponding instantaneous streamflows (streamflow at the time of sample collection), were collected during rise, peak, and fall flow conditions. Representative water-quality samples were collected using equal-width increment (EWI) techniques and discrete-sampling methods as outlined in the National Field Manual for the Collection of Water Quality Data (Wilde and others, 1999a). For EWIs, the stream cross section was divided into equal-increment widths, and samples were collected at the center of each increment by lowering and raising a sampler through the water column (Wilde and others, 1999a). Discrete (point) samples were collected at one location along the stream cross section by opening and closing a sampler at a specified depth (Wilde and others, 1999a). The Cypress Creek water-quality sampling record began with approximately quarterly (occurring about every 3 months) and high-flow event sampling from November 23, 2010, through present (February 28, 2014) (U.S. Geological Survey, 2012b) following protocols outlined by Edwards and Glysson (1999). The USGS Missouri Water Science Center Sediment Laboratory in Rolla, Missouri, analyzed samples for suspended-sediment concentration following procedures established in Guy (1969). To maintain proper quality assurance and quality control (QA/QC) of water-quality data, protocols for instrument calibration (Wilde and Radke, 1998; Wilde and others, 1998a,b) and equipment cleaning (Wilde and others, 1998c) were followed. Streamflow data measured from July 8, 2009, through September 30, 2012, and waterquality data collected from November 23, 2010, through June 20, 2012, are presented in this report.

\section{Subwatershed Delineation and Land Use}

The HSPF model requires a set of hydrologically similar land areas based on land use, surficial geology, soil characteristics, and other factors that represent the watershed. These hydrologically similar areas are grouped into subwatersheds containing pervious land segments (PERLND) and impervious land segments (IMPLND), each of which simulates the water-quantity and quality processes through the conceptual pathways of the hydrologic cycle (Ockerman and Heitmuller, 2010). Subwatersheds (fig. 4) were delineated based on NED and automatic delineation tools within a Geographic Information System (GIS) and were adjusted manually based on the NHD stream reaches and well-pad locations. There are a total of 105 subwatersheds, split between two HSPF models that are linked together (55 in the upper part and 50 in the lower part) (fig. 4), characterizing Cypress Creek's watershed. Each subwatershed and its associated PERLND and IMPLND drain into a stream segment called a reach reservoir (RCHRES). There is one RCHRES per subwatershed and each RCHRES subsequently drains downstream (fig. 4). Land use was determined from the 


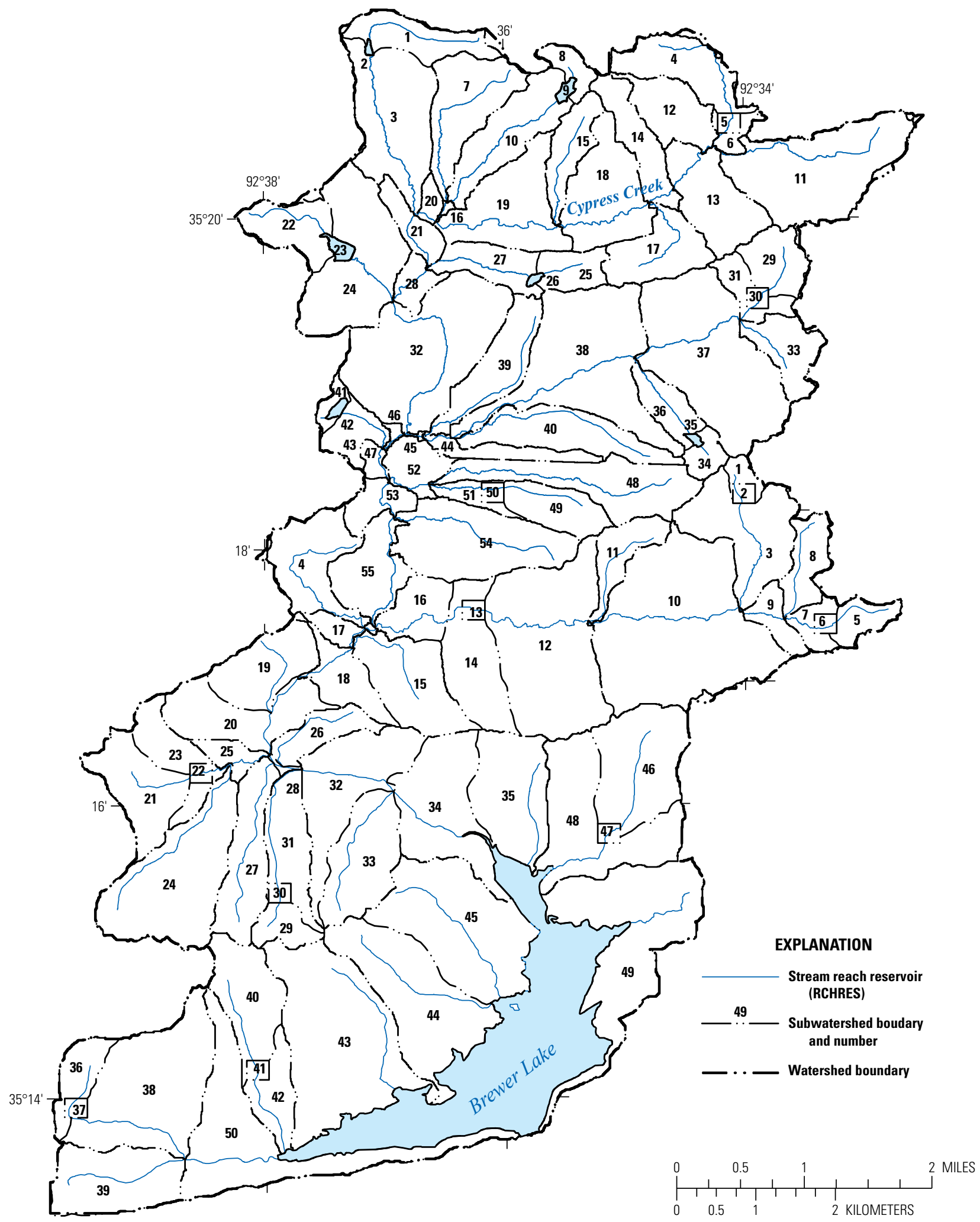

Base from U.S. Geological Survey digitial data, 2008, 1:24,000 Universal Transverse Mercator projection, zone 15

Figure 4. Locations of the subwatersheds and reaches within the Cypress Creek watershed used for the Hydrologic Simulation Program-FORTRAN model. 
Arkansas 2006 land-use dataset (Arkansas Natural Resources Commission and University of Arkansas: Center for Advanced Spatial Technologies, 2009). The land use was categorized into nine PERLND types and five IMPLND types. IMPLNDs were assigned as a percentage of the PERLND based on the land-use datasets. Eleven of the subwatersheds were created to represent potential surface-water impoundments in the scenario simulations (shown as squares on fig. 4); the areas within these subwatersheds retained the same hydrologic features (land use, slope, and others) as that of the current-conditions simulation and were adjusted only during scenario simulations.

\section{Pervious and Impervious Land Segments}

The water-quality and quantity processes that occur on the land surface before entering a stream segment are simulated within each PERLND or IMPLND module. The processes that occur within the PERLNDs include water movement by three components: surface runoff, interflow, and groundwater; whereas, the processes that occur within the IMPLNDs include only surface runoff and no infiltration occurs. Runoff is simulated for each PERLND or IMPLND independently, and a water balance is calculated for each time step throughout the simulation. Surface runoff associated with the PERLNDS and IMPLNDs is routed into a RCHRES within the associated subwatershed. Interflow and groundwater within the PERLNDs account for water that is not evaporated or moved off the land surface from direct runoff. Interflow accounts for water that is directly infiltrated to the upper soil zone, is moved to overland flow from surface storage, or is removed from interflow storage to shallow subsurface flow.
Groundwater accounts for the water that infiltrates to the lower soil zone and groundwater storage. The water retained as groundwater storage reappears as base flow or is lost from the system through deep percolation.

\section{Reach Characterization}

Within each subwatershed, water and associated waterquality constituents drain from the PERLNDs and IMPLNDs into a RCHRES. Each RCHRES (fig. 4) within the HSPF model is characterized by a piecewise linear function table (FTABLE) and is developed based on channel geomorphology, width, depth, length, slope, and roughness obtained from the NED and NHD for streamflow routing. FTABLEs are independent of the shape of the water body but serve to relate stage to surface area, channel volume, and discharge and are based on the one-dimensional kinematic wave theory for each RCHRES (Moore and Mohamoud, 2007; Bicknell and others, 2001). The assumptions made to calculate water movement through a reach are (1) flow within a RCHRES is assumed to be well-mixed and unidirectional; (2) inflows enter a RCHRES at its upstream limit; and (3) precipitation, evaporation, and fluxes from the PERLNDs and IMPLNDs influence processes that occur within the RCHRES.

Within the Cypress Creek watershed, six subwatersheds (table 2) were represented as RCHRESs only, meaning there was no PERLND or IMPLND associated within the subwatershed (fig. 4). This was done to best represent surfacewater impoundments (fig. 3 ) within the watershed. Only surface-water impoundments that had a surface area greater than 3 acres were included because smaller ponds have negligible effects on the hydrology.

Table 2. Withdrawals and surface-water impoundment volumes for use in the Cypress Creek watershed model.

[RCHRES, Hydrologic Simulation Program—FORTRAN reach reservoir (RCHRES)]

\begin{tabular}{lcccccc}
\hline & RCHRES 2 & RCHRES 9 & RCHRES 23 & RCHRES 26 & RCHRES 35 & RCHRES 42 \\
\hline Average depth (feet) & 3.2 & 10 & 10.1 & 7.1 & 6.4 & 8.3 \\
Area (acres) & 3.3 & 10.5 & 17.5 & 5.1 & 5.2 & 8.4 \\
Volume (acre-feet) & 10.6 & 105.0 & 176.8 & 36.2 & 33.3 & 69.7 \\
70 percent volume & 7.39 & 73.50 & 123.73 & 25.35 & 23.30 & 48.80 \\
Volume per second (ft $\left.^{3} / \mathrm{s}\right)$ & 1.57 & 5.57 & 5.57 & 5.57 & 5.57 & 5.57 \\
Days withdrawn per year $^{1}$ & 5.0 & 13.0 & 22.0 & 5.0 & 4.0 & 9.0 \\
\hline
\end{tabular}

${ }^{1}$ Days withdrawn are for two times per year, once in spring and once in fall. 


\section{Meteorological Data}

The sparseness of available rain-gage data in small watersheds has been a severe hindrance to accurate hydrologic modeling in the past; however, NEXRAD data were used as the precipitation input for the HSPF model (National Oceanic and Atmospheric Administration, 2008). As part of the NEXRAD program, the National Weather Service River Forecasting Centers produce gridded precipitation estimates; these estimates are known as Multisensor Precipitation Estimator (MPE) data (National Oceanic and Atmospheric Administration, 2010). MPE data are based from Doppler radar precipitation data and replace the earlier Stage III NEXRAD product (National Oceanic and Atmospheric Administration, 2008). The MPE algorithms provide better gage-correction biasing, mosaicking of radar data, and can incorporate satellite-derived precipitation estimates into the final MPE data product (National Oceanic and Atmospheric Administration, 2002). The MPE data offer precipitation estimates spatially averaged over grid cells of about $6 \mathrm{mi}^{2}$ on a 1-hour time step (fig. 5). The Weather Surveillance Radar - 1998 Doppler (WSR-88D) that provides raw radar data for the Cypress Creek watershed is located approximately 41 mi south of the watershed; a single WSR-88D beam has an effective range of approximately $143 \mathrm{mi}$ (U.S. Army Corps of Engineers, 1994). The NEXRAD precipitation data provide hourly estimates in the Hydrologic Rainfall Analysis Project (HRAP) grid system, about a 2.5-mi grid in a Polar Stereographic map projection (Shedd and Fulton, 1993). The HRAP grid (Greene and Hudlow, 1982) is used to identify the location of each NEXRAD precipitation value. These spatially distributed precipitation data can be incorporated into watershed models as an improvement to using the sparse raingage networks to obtain rainfall data (Ockerman and Roussel, 2009; Soong and others, 2005).

The HRAP grid cells with the hourly MPE precipitation time series were intersected with each of the subwatersheds of the HSPF model using standardized functions within a GIS. The amount of precipitation for each subwatershed was determined by using a weighted average of the percentage of subwatershed area covered by each HRAP grid cell. For example, if the entire area of one subwatershed is within one HRAP grid cell, the subwatershed would receive a proportionate amount of precipitation equivalent to the amount of HRAP grid cell area covered by the subwatershed; if a subwatershed is split by more than one HRAP grid cell, each grid cell precipitation value is multiplied by the percentage of subwatershed area that falls within each HRAP cell, and then all products are summed together.

During the model simulation time period of January 2008 through September 30, 2012, Arkansas experienced the ninth driest year (2010) on record (1895-2011), with only 39.1 inches of precipitation, and the wettest year (2009) on record, with 72.7 inches of precipitation (National Oceanic and Atmospheric Administration, 2012a); the average annual precipitation for Arkansas from 1895-2011 was 49.5 inches (National Oceanic and Atmospheric Administration, 2012a). Additional HSPF model input data included hourly potential evapotranspiration estimates determined from minimum and maximum daily temperature, as well as watershed latitude, using the Hamon method (Hummel and others, 2001) within a preprocessor (U.S. Environmental Protection Agency, 2003).

\section{Evaluation Methods for the Hydrologic Simulation Program-FORTRAN}

Various methods can be used to evaluate the acceptance criteria of model calibration. Model calibration is an iterative process of simulation, parameter evaluation, and adjustment to achieve an acceptable match of simulated and measured values. Model validation was not performed for the HSPF model because of the limited data for calibration (July 8, 2009-September 30, 2012, at one USGS streamflow-gaging station). The calibration period (July 8, 2009-September 30, 2012) included an extreme dry and wet year, a normal year, and a year when precipitation was slightly above normal. Randomly removing one or more years from the calibration dataset to use for validation would have potentially removed essential values needed to calibrate the model for the range of hydrologic conditions. Instead, all of the recent calibration data in the calibration process were included to obtain the most accurate representative model.

Several statistical methods calculated for the calibration period (July 8, 2009-September 30, 2012) for the USGS streamflow-gaging station were used to evaluate the HSPF model streamflow calibration including: streamflow volumes, Spearman's rho, the Nash-Sutcliffe model efficiency coefficient (NSE), the Mean Absolute Error (MAE), Root Mean Square Error (RMSE), and Percent Bias (PBIAS). The HSPF model statistics for water-quality constituents (suspended sediment) included daily mean values, mean percent error, MAE, RMSE, NSE, and PBIAS for the daily values.

Spearman's rho was calculated to determine the correlation between simulated and measured values of streamflow and suspended sediment (Helsel and Hirsch, 2002). The NSE measures the magnitude of the differences between the measured and simulated values and is computed by equation 1 :

$$
N S E=1-\frac{\sum_{t=1}^{T}(\text { measured value }- \text { simulated value })^{2}}{\sum_{t=1}^{T}(\text { measured value }-\overline{\text { measured value }})^{2}}
$$

where

$T$ is time, in days; and

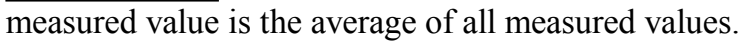




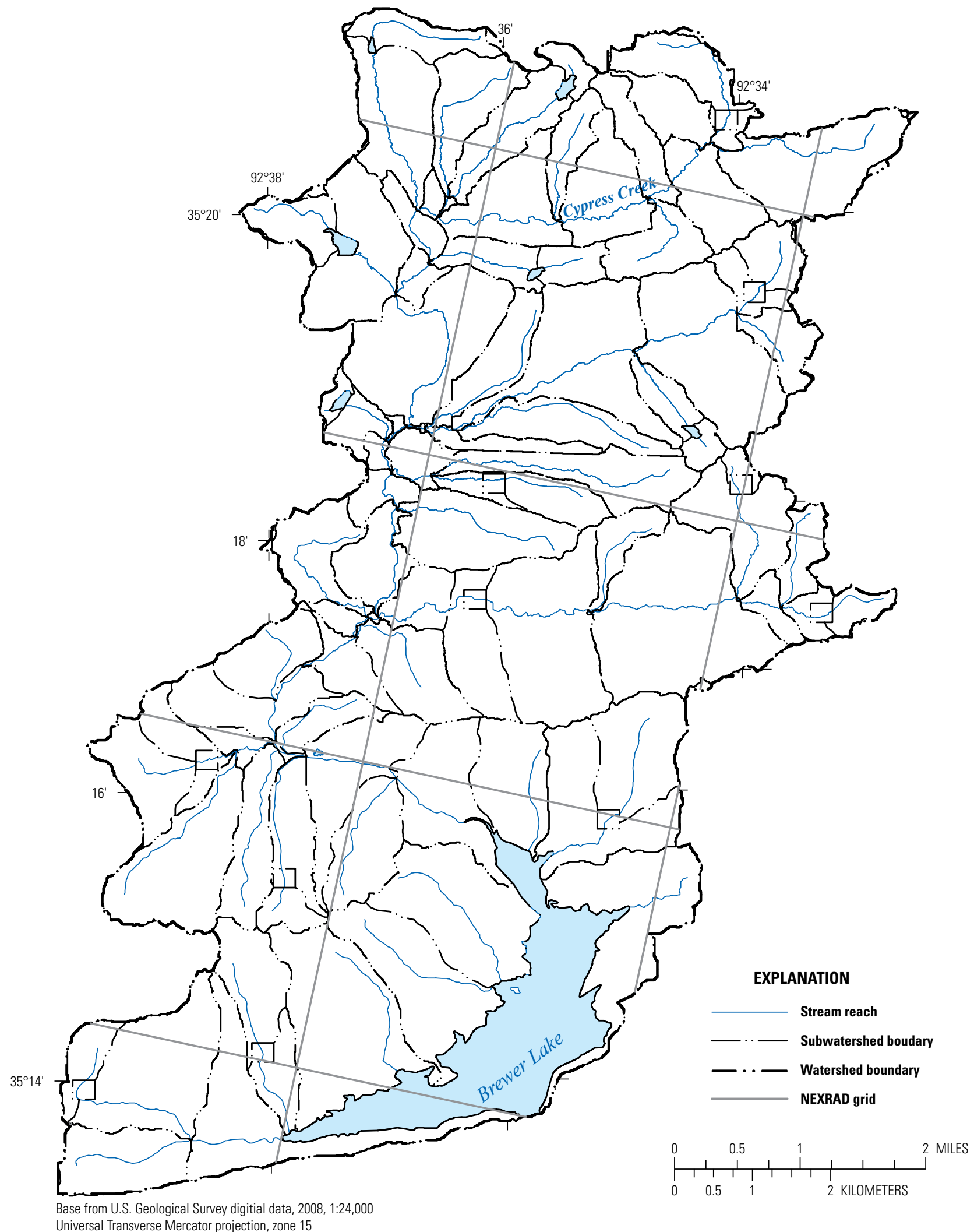

Figure 5. Location of the Next Generation Radar (NEXRAD) grid, Cypress Creek watershed, Arkansas. 
A NSE of 1 indicates model predictions are a perfect match to the observed data, and a NSE of equal to or less than 0 indicates that the mean measured value is a better predictor than the simulated value and is considered unacceptable (Moriasi and others, 2007). MAE provides the error between the simulated and measured values and is computed by equation 2:

$$
M A E=\sum \frac{\mid \text { simulated value }- \text { measured value } \mid}{\text { number of observations }} .
$$

For example, a $M A E$ of $17.3 \mathrm{ft}^{3} / \mathrm{s}$ indicates that the mean difference between simulated streamflow and measured streamflow is $17.3 \mathrm{ft}^{3} / \mathrm{s}$. The RMSE indicates the spread of how far the simulated values deviate from the measured values and is computed by equation 3 :

$$
R M S E=\sqrt{\frac{\sum(\text { simulated value }- \text { measured value })^{2}}{\text { number of observations }} .}
$$

For example, a RMSE of $8.25 \mathrm{ft}^{3} / \mathrm{s}$ indicates that the simulated streamflow is within $8.25 \mathrm{ft}^{3} / \mathrm{s}$ of the measured streamflow. PBIAS measures the average tendency of the simulated data to be larger or smaller than their observed counterparts (Gupta and others, 1999) and is computed by equation 4 :

$$
P B I A S=\frac{\sum_{t=1}^{T}(\text { measured value }- \text { simulated value }) \times 100}{\sum_{t=1}^{T}(\text { measured value })} .
$$

A PBIAS of 0 indicates optimal performance, with low-magnitude values indicating accurate model simulation (Moriasi and others, 2007).

\section{Hydrologic Simulation Program- FORTRAN Model Calibration}

Hourly streamflow data and suspended sediment concentration data were used to calibrate the HSFP model. The model covered the period from July 8, 2009, through September 30, 2012, and used continuous streamflow and water-quality data from Cypress Creek (USGS station 07261090) for calibration. Calibration is a necessary step to check the reliability of the model. Prior to calibration, meteorological data for the entire 2008 calendar year was input to the HSPF model, as well as the period leading up to the start of the modeling period (July 8, 2009) for the model to "warmup." This warmup period is a necessary step to allow for soil moisture to stabilize and constituent accumulation and washoff to equilibrate. Comparisons between the currentconditions simulation and scenario simulations were made for the calibration period (July 8, 2009-September 30, 2012) for streamflow and suspended-sediment analyses.

For the HSPF model current-conditions simulation, several conditions were considered:

1. The surface-water impoundments within the watershed (figs. 3-4) were withdrawn to 70 percent of their total volume over a variable period, two times per year (once in spring and once in summer) (table 2);

2. Withdrawal from Cypress Creek occurred during the same time of year as item 1 (for 6.5 days, two times per year [once in spring and once in summer] at a rate of $1.39 \mathrm{ft}^{3} / \mathrm{s}$ when the simulated streamflow at the Cypress Creek streamflow-gaging station at the time of withdrawal was at least $12 \mathrm{ft}^{3} / \mathrm{s}$ ), simultaneously from four separate locations along Cypress Creek (fig. 3); and

3. The rates and volumes of withdrawal for items 1 and 2 were determined based on the assumption that 245 hydraulic fracturing jobs ( 7 wells per 35 pads) during the simulation period would occur, and 4.73 million gallons (14.5 acre-ft) of water would be needed for each gas well. The water demand of 4.73 million gallons is removed only from the surface-water impoundments and Cypress Creek, and no recycled water is assumed, which currently accounts, on average, for 35 percent of the total hydraulic fracturing volume (Southwestern Energy Co., written commun., 2011).

\section{Streamflow Calibration}

Several HSPF model parameters (table 3) govern the simulated flux of water into a RCHRES. Primary parameters that reflect soil conditions simulated from the PERLNDs (and therefore determine the distribution of available water for infiltration or for runoff) include lower zone nominal storage (LZSN), upper zone nominal storage (UZSN), infiltration capacity of soil (INFILT), and lower zone evapotranspiration (LZETP). Parameters that affect surface runoff simulated from IMPLNDs are length of assumed overland flow plane (LSUR), slope of the assumed overland flow plane (SLSUR), Manning's $n$ for assumed overland flow plane (NSUR), and the retention storage capacity of the surface (RETSC).

The simulated total flow volume and average daily mean streamflow rate matched well with the measured data at the Cypress Creek gage. Streamflow calibration results (percent errors) for average daily mean flow rate and total flow volume (table 4) generally were within the acceptance rating criteria of "very good" (less than 10 percent) for HSPF model performance (Donigian, 2000). The measured average daily mean streamflow rate was $36.6 \mathrm{ft}^{3} / \mathrm{s}$ for the period of 
Table 3. Summary of calibrated values for selected hydrology parameters for the Hydrological Simulation Program—FORTRAN model of the Cypress Creek watershed.

[PERLND, pervious land area; IMPLND, impervious land area; numbers in bold are HSPF default values (Bicknell and others, 2001)]

\begin{tabular}{|c|c|c|c|c|}
\hline Parameter & Land surface & Description & Values & Units \\
\hline AGWRC & PERLND & Base groundwater recession & 0.85 & 1/day \\
\hline CEPSC & PERLND & Interception storage capacity & $0.01-0.25$ & Inches \\
\hline DEEPFR & PERLND & Fraction of groundwater inflow to deep recharge & 0.46 & Dimensionless \\
\hline INFEXP & PERLND & Infiltration equation exponent & 2.0 & Dimensionless \\
\hline INTFW & PERLND & Interflow index & $3.00-5.00$ & Dimensionless \\
\hline IRC & PERLND & Interflow recession coefficient & $0.45-0.55$ & 1/day \\
\hline KVARY & PERLND & Groundwater outflow modifier & 2.9 & $1 /$ inches \\
\hline LSUR & PERLND or IMPLND & Length of assumed overland flow plane & $200-400$ & Feet \\
\hline LZETP & PERLND & Lower zone evapotranspiration & $0.10-0.85$ & Dimensionless \\
\hline UZSN & PERLND & Upper zone nominal storage & $0.69-0.76$ & Inches \\
\hline
\end{tabular}

Table 4. Hydrological Simulation Program—FORTRAN streamflow calibration results for the Cypress Creek watershed.

[acre-ft, acre-feet; $\mathrm{ft}^{3} / \mathrm{s}$, cubic feet per second; <, less than]

Cypress Creek near Birdtown (07261090)

Calibration period July 8, 2009, to September 30, 2012

\begin{tabular}{|c|c|c|c|}
\hline Streamflow volumes ${ }^{1}$ & Measured & Simulated & $\begin{array}{c}\text { Percent } \\
\text { error }^{2}\end{array}$ \\
\hline Total streamflow volume (acre-ft) & 79,035 & 78,285 & -0.95 \\
\hline Average daily mean streamflow rate $\left(\mathrm{ft}^{3} / \mathrm{s}\right)$ & 36.6 & 34.5 & -5.61 \\
\hline Total of highest 10 percent of daily streamflows (acre-ft) & 56,318 & 58,653 & 4.15 \\
\hline Total of lowest 50 percent of daily streamflows (acre-ft) & 571 & 670 & 17.4 \\
\hline Model-fit statistics $^{1}$ & Daily & & \\
\hline Number of days & 1,138 & & \\
\hline Spearman's rho & 0.70 & & \\
\hline$p$ value & $<0.001$ & & \\
\hline Nash-Sutcliffe model efficiency coefficient (NSE) & 0.77 & & \\
\hline Mean absolute error (MAE) $\left(\mathrm{ft}^{3} / \mathrm{s}\right)$ & 21.1 & & \\
\hline Root mean square error (RMSE) $\left(\mathrm{ft}^{3} / \mathrm{s}\right)$ & 66.9 & & \\
\hline Percent bias (PBIAS) (percent) & 5.60 & & \\
\hline
\end{tabular}

\footnotetext{
${ }^{1}$ Only paired data were used in statistical calculations; missing data were not used.
}

${ }^{2}$ Percent error is simulated minus measured divided by measured times 100 . 
record, and the simulated average daily mean streamflow rate for the same time period (July 8, 2009-September 30, 2012) was $34.5 \mathrm{ft}^{3} / \mathrm{s}$ (fig. 6); this is an error of -5.61 percent (table 4). In general, based on the exceedance probability, simulated "low flows" (in this instance, flows with exceedance probabilities greater than 50 percent) were within the acceptance rating criteria of "fair" for the total of the lowest 50 percent of daily streamflows (17.4 percent) for the Cypress Creek gage (table 4, fig. 7) (Donigian, 2000). Additionally, simulated and observed high flows (highest 10 percent of daily streamflows) were within the acceptance rating criteria of "very good" with a 4.15-percent difference at the Cypress Creek gage (table 4, fig. 6) (Donigian, 2000). Percentage error between the measured and simulated total streamflow volume was -0.95 percent (table 4 ), a performance rating of "very good" (Donigian, 2000). Temporally, the streamflow calibration matched the seasonal variability occurring during low streamflow conditions (streamflows not substantially influenced by runoff) (fig. 6), and the simulated peak flows generally undersimulated high streamflow conditions. Specifically, simulated values were higher than measured values for the highest 10 percent of daily streamflows (table 4) probably because simulated and measured values for the highest 10 percent of daily streamflows did not occur on the same day (fig. 6).

Based on the additional model-fit statistics, the simulated and measured average daily mean streamflow rates matched well at the Cypress Creek gage. Performance ratings for the given statistics were reported by Moriasi and others (2007) and Donigian (2000) (table 4). For the Spearman's rho (0.70), NSE (0.77), and PBIAS (5.60 percent), the model performance falls within the "satisfactory" and "very good" rating, respectively. The MAE and RMSE for the simulated average daily mean streamflow and the measured average daily mean streamflow rate were 21.1 and $66.9 \mathrm{ft}^{3} / \mathrm{s}$, respectively (table 4 ).

\section{Suspended-Sediment Calibration}

To calibrate suspended-sediment loads entering streams, it is desirable to calibrate loads from each of the land-use types to known values. However, no suspended-sediment studies have been conducted within the Cypress Creek watershed. As such, suspended-sediment loading rates from each land use were obtained from literature values, which can range substantially from study to study (Bureau of Land Management, 2006; Donigian and Love, 2003; U.S. Environmental Protection Agency, 1999; Maryland Department of the Environment, 2006; Scoles and others, 2001; Tetra Tech Inc., 2004) (table 5). For the Cypress Creek watershed, the middle to upper range of the suspendedsediment loading rates reported in the literature for relative land uses was used for calibration (table 5).
Table 5. Land-use loading rates for the Hydrological Simulation Program-FORTRAN model of the Cypress Creek watershed.

[Loading rates for constituents are sums of annual loads for the listed constituent divided by the acres for each land-use type; (ton/acre)/yr, ton per acre per year. Loading rate values are determined from given literature values (Bureau of Land Management, 2006; Donigian and Love, 2003; U.S. Environmental Protection Agency, 1999; Maryland Department of the Environment, 2006; Scoles and others, 2001; Tetra Tech Inc., 2004)]

\begin{tabular}{lc}
\hline \multicolumn{1}{c}{ Land use } & $\begin{array}{c}\text { Suspended sediment } \\
\text { ([ton/acre]/yr) }\end{array}$ \\
\hline Deciduous forest & 0.48 \\
Evergreen forest & 0.39 \\
Mixed forest & 0.46 \\
Gravel roads & 1.7 \\
Pasture & 1.2 \\
Pads & 1.2 \\
Shrub & 1.1 \\
Urban & 0.89 \\
\hline
\end{tabular}

Two equations are used in the HSPF model to calculate the production, removal, and transport of suspended sediment from the land surface for three sediment size classes (sand, silt, and clay). These equations are included in the Agricultural Runoff Model (ARM) and Nonpoint Source (NPS) models developed by Donigian and Davis (1978) and Donigian and Crawford (1977), respectively, which are used in the HSPF model. The production of sediment is simulated by detachment of soil by precipitation, removal of sediment by scour of the soil matrix, and transport of the detached sediment by overland flow. Suspended-sediment load within a RCHRES is calculated from particle size, soil texture, settling velocity, density, and erodibility and is simulated by convection, scouring, and deposition. Value ranges and units for calibrated HSPF model suspended-sediment parameters are listed in table 6.

The mid- to upper-range suspended-sediment loading rates, as reported in the literature for different land uses, worked reasonably well to calibrate the suspended-sediment concentrations at the Cypress Creek gage. For suspendedsediment concentrations at Cypress Creek, the mean measured suspended-sediment concentration was $290.9 \mathrm{mg} / \mathrm{L}$ and the mean simulated suspended-sediment concentration was $373.6 \mathrm{mg} / \mathrm{L}$, with a mean percent error between the paired data of -0.8 percent (table 7; fig. 8 ). Additionally, percent error (relative to the measured value) ranged from -301.0 to 99.9 percent (table 7). Based on Moriasi and others (2007), the PBIAS value (-28.5 percent) is "good" for sediment calibration. The MAE, RMSE, and Spearman's rho for the paired-simulated suspended-sediment concentrations and the measured suspended-sediment concentrations were $235.1 \mathrm{mg} / \mathrm{L}, 480.3 \mathrm{mg} / \mathrm{L}$, and 0.72 , respectively (table 7). 


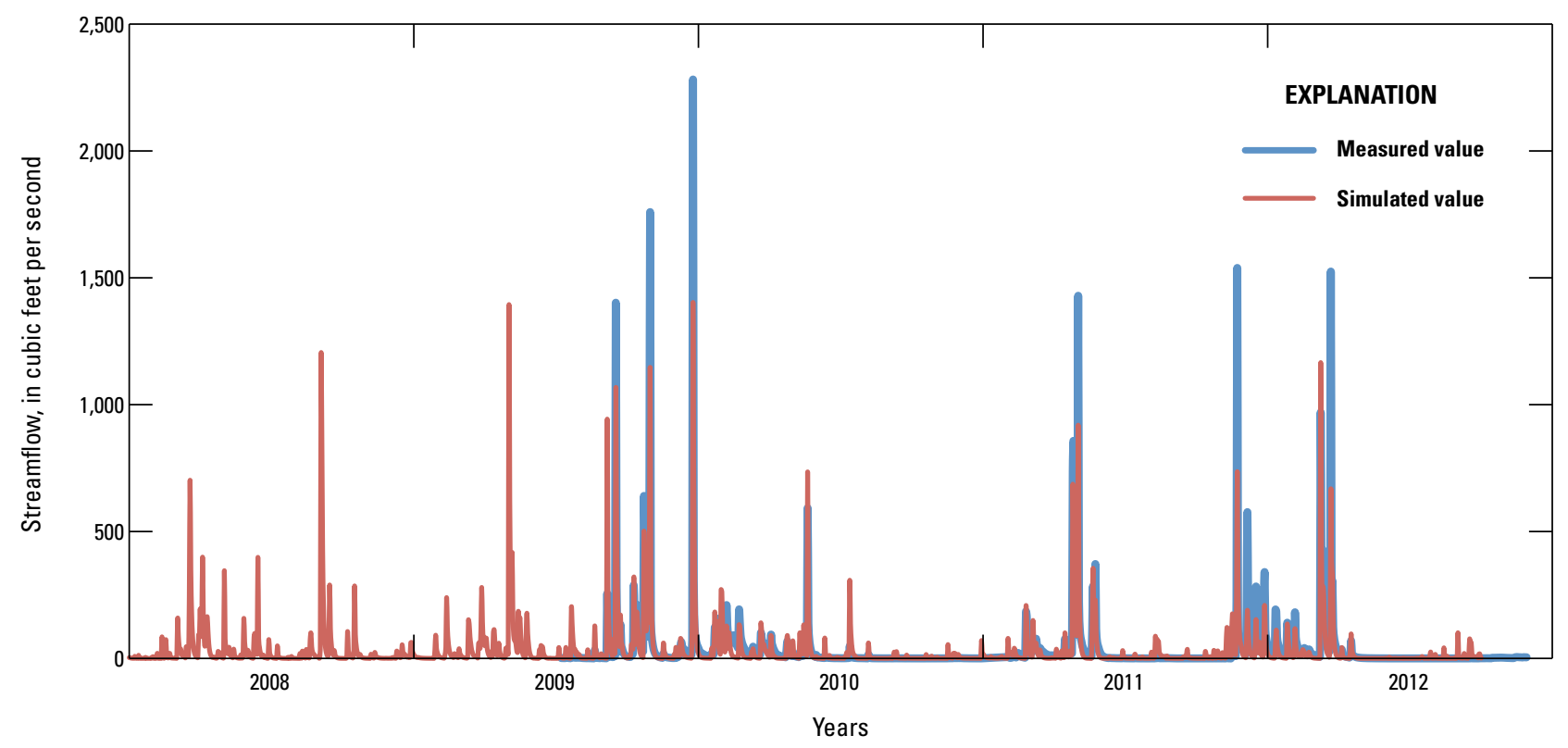

Figure 6. Simulated and measured daily mean streamflow at the Cypress Creek gage in the Cypress Creek watershed.

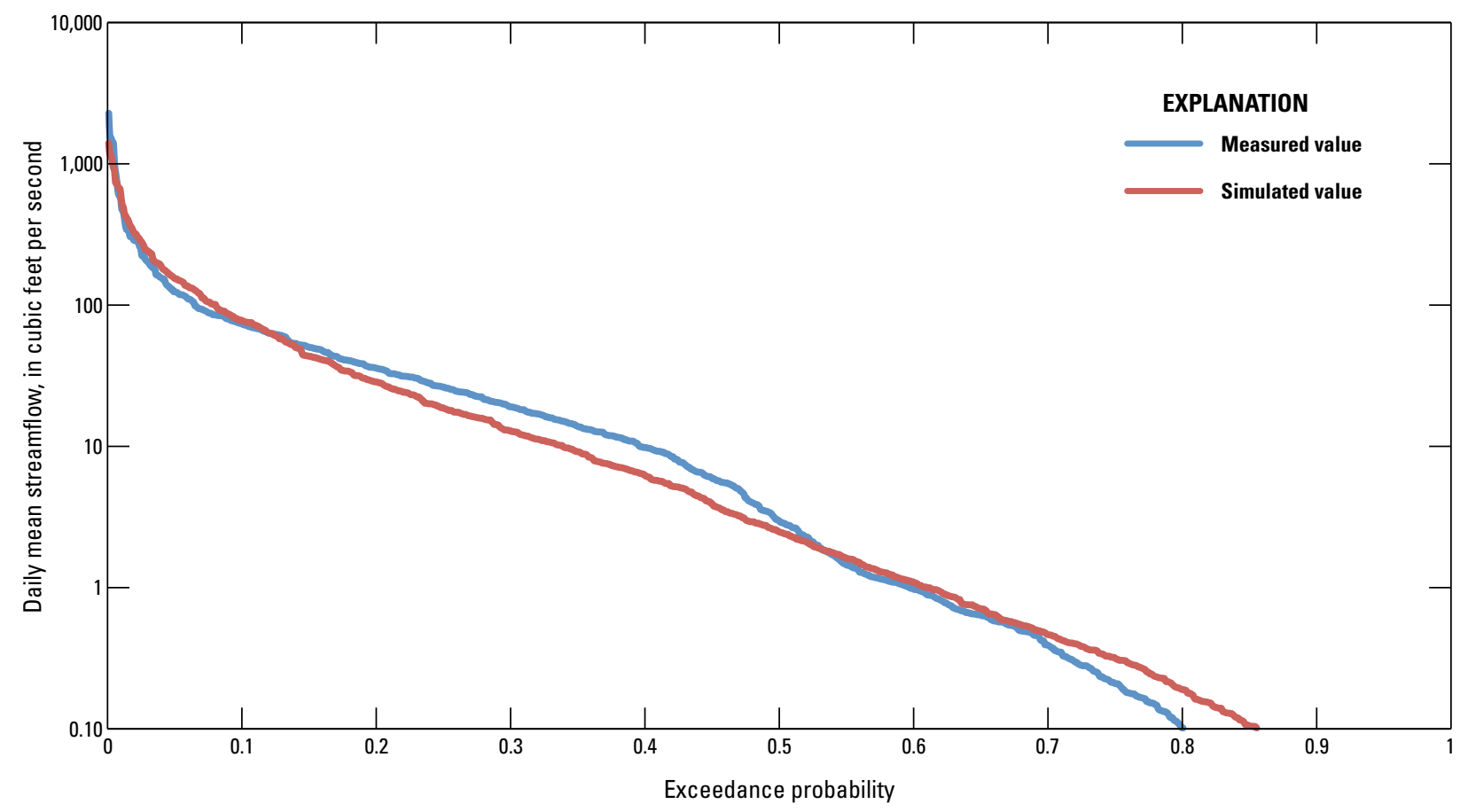

Figure 7. Exceedance probability of simulated and measured daily mean streamflow at selected inflow stations in the Cypress Creek watershed. 
Table 6. Summary of calibrated values for suspended-sediment parameters for the Hydrological Simulation ProgramFORTRAN model of the Cypress Creek watershed.

[PERLND, pervious land surface, IMPLND, impervious land surface, RCHRES, stream reach; -, none; numbers in bold are Hydrologic Simulation ProgramFORTRAN default values (Bicknell and others, 2001)]

\begin{tabular}{|c|c|c|c|c|}
\hline Parameter & $\begin{array}{c}\text { Land } \\
\text { surface }\end{array}$ & Description & Values & Units \\
\hline KRER & PERLND & Coefficient of the soil-detachment equation & $0.28-0.43$ & Complex \\
\hline KSER & PERLND & Coefficient of the detached-sediment washoff equation & $0.030-4.175$ & Complex \\
\hline JSER & PERLND & Exponent of the detached-sediment washoff equation & 1.50 & Complex \\
\hline AFFIX & PERLND & $\begin{array}{l}\text { Fraction by which detached sediment decreases daily through soil } \\
\text { compaction }\end{array}$ & $0.06-0.45$ & $1 /$ day \\
\hline NVSI & PERLND & Rate at which sediment enters detached storage from the atmosphere & $\mathbf{0}$ & Pound/acre-day \\
\hline KEIM & IMPLND & Coefficient of the solids washoff equation & $0.30-0.55$ & Complex \\
\hline JEIM & IMPLND & Exponent of the solids washoff equation & 2.00 & Complex \\
\hline ACCSDP & IMPLND & Solids accumulation rate & 0.0005 & Ton/acre-day \\
\hline RHO & RCHRES & Density of the sediment particle & 2.6 & Gram/cubic centimeter \\
\hline TAUCS (silt) & RCHRES & Critical bed shear stress for sediment scour & $0.03-9.0$ & Pound/square foot \\
\hline TAUCD (clay) & RCHRES & Critical bed shear stress for sediment deposition & $0.002-8.6$ & Pound/square foot \\
\hline TAUCS (clay) & RCHRES & Critical bed shear stress for sediment scour & $0.03-9.0$ & Pound/square foot \\
\hline
\end{tabular}

${ }^{1}$ Calibration only parameter (U.S. Environmental Protection Agency, 2006).

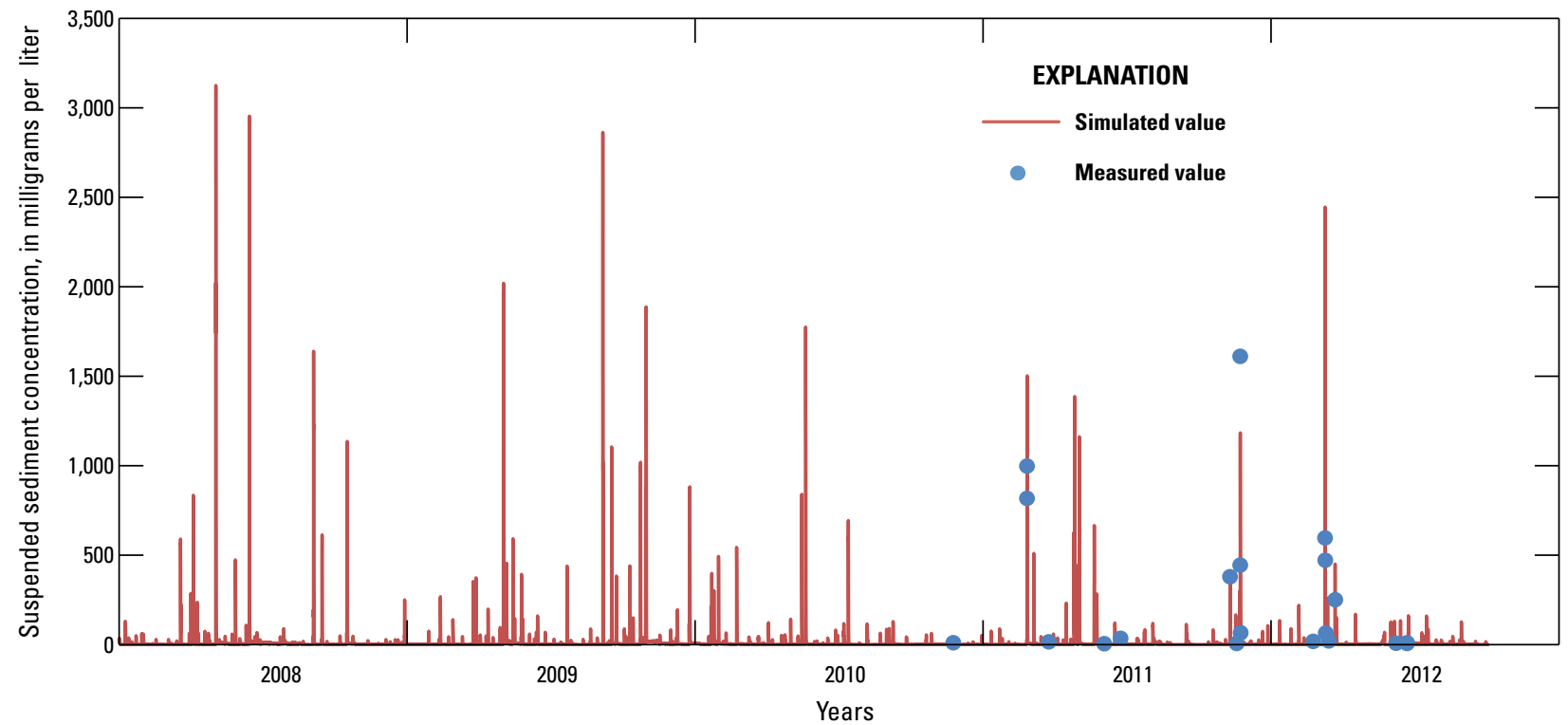

Figure 8. Simulated and measured suspended-sediment concentrations at Cypress Creek near Birdtown. 
Table 7. Measured and simulated suspended-sediment concentrations and suspended-sediment calibration statistics for the Hydrological Simulation Program—FORTRAN model at Cypress Creek near Birdtown.

$[\mathrm{mg} / \mathrm{L}$, milligrams per liter; the measured instantaneous concentrations, collected from October 1, 2010, through September 30, 2012, were averaged. Hourly simulated values were paired with measured values for the nearby observed hour]

Cypress Creek near Birdtown (07261090)

Calibration period October 1, 2010, to September 30, 2012

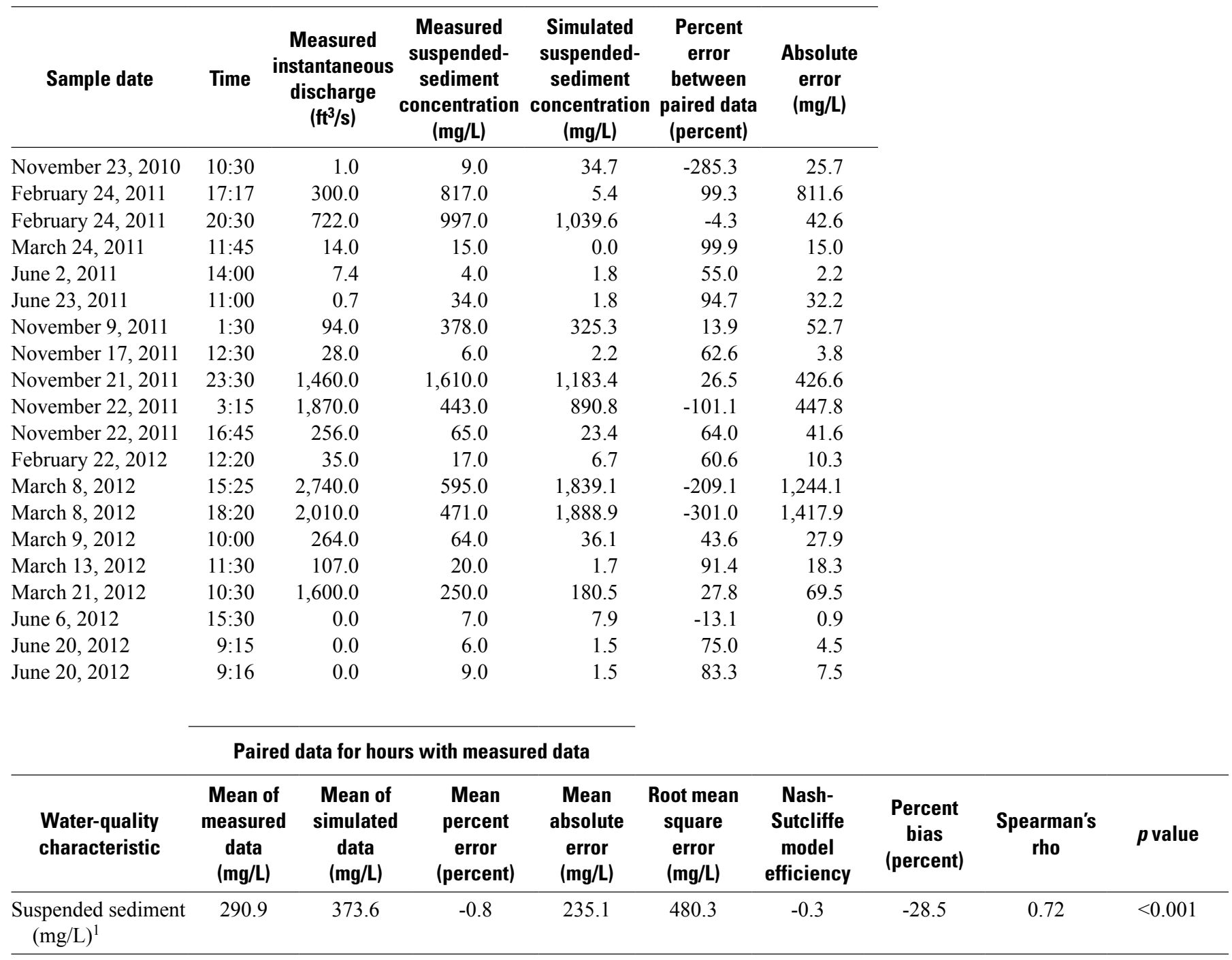

\footnotetext{
${ }^{1}$ Suspended sediment LRL: $1 \mathrm{mg} / \mathrm{L}$.
} 


\section{Hydrologic Simulation Program- Fortran Model Limitations}

An understanding of model limitations is essential for the effective use and interpretation of watershed models. The accuracy of the HSPF model is limited by the simplification of complexities with the physical properties of streamflow, hydrodynamics within the watershed, water-quality processes within the watershed, spatial and temporal discretization effects, and assumptions made in the formulation of the governing equations. Model accuracy is limited by subwatershed size, boundary conditions, accuracy of calibration, and parameter sensitivity; model accuracy also is limited by the availability of appropriate data and by the interpolations and extrapolations that are inherent in using data in any model. For example, streamflow and water quality can be simulated with reasonable accuracy at stream or reservoir locations with a streamflow- or water-quality gaging station; however, for tributaries that do not have gaging stations, adequacy of streamflow simulation is uncertain. Further, landuse sediment loading rates were assumed for the HSPF model (table 5), but site-specific data collection for different land-use types in the Cypress Creek watershed could improve model calibration. Field QA/QC samples, such as replicates, were not collected for this study; therefore, variability associated with sediment data collection is unknown. Although a model might be considered calibrated, calibration parameter values are not unique in yielding acceptable simulated values of streamflow or water-quality characteristics.

Sensitivity analysis is the determination of the effects of small changes in calibrated model parameters on model results. A complete sensitivity analysis was not conducted for all model parameters in the Cypress Creek watershed model. The HSPF model includes more than 150 parameters (tables 3 and 6 list subsets of the parameters; default values in Bicknell and others [2001] were used for several other parameters), and a complete sensitivity analysis would be a very lengthy process; however, many hydrodynamic and water-quality simulations were conducted as a component of model calibrations. Results from these simulations form the basis for the sensitivity analysis.

For the HSPF model, parameter sensitivity is a function of the physical conditions of Cypress Creek's watershed, such as climate, topography, soils, and vegetation. For the simulation of streamflow, LZSN and INFILT (both of which play a direct role in determining whether moisture on the land surface infiltrates, enters storage, or becomes runoff) typically are the most sensitive hydrologic parameters (Al-Abed and Whiteley, 2002; Ryu, 2009; Skahill, 2004; Skahill and Doherty, 2006). Parameters related to detachment and washoff of sediment from the land surface, as well as the parameters related to shear stress within the RCHRES, such as critical bed shear stress for sediment deposition (TAUCD) and critical bed shear stress for sediment scour (TAUCS), typically appeared to be among the most sensitive parameters for simulation of suspended sediment within the Cypress Creek watershed HSPF model.

During storm events, it is difficult to be at a given site to sample the rising flow, which presumably corresponds with the peak in suspended-constituent concentration. As such, the model is limited by the paucity of data. To adequately predict and match simulated to measured values through entire stormflow events, samples would have to be collected along the entire stormflow hydrograph. Although overall positive linear relations are found, for example, between streamflow and suspended sediment, there usually is large variation between instantaneous measurements as a result of numerous variables. The resulting low coefficient of determination values normally will reflect this variation as a result of sampling timing, difficulty in collecting representative samples, and varying landscape characteristics. As such, the model may actually perform much better as a predictive tool (especially for seasonal or annual loads rather than instantaneous or daily concentrations) than is reflected in attempts at matching individual simulations to instantaneous measurements.

\section{Simulated Effects of Proposed Gas Extraction Activities on the Streamflow and Sedimentation within the Cypress Creek Watershed}

The calibrated HSPF model is referred to as "currentconditions simulation" in the following discussions of scenarios. Comparisons between the current-conditions simulation and four scenario simulations were made for the calibration period (July 8, 2009-September 30, 2012) for streamflow and suspended-sediment loads. The four scenarios represent simulated changes in land use and examine the potential effects of these land-use changes on the water quality within the Cypress Creek watershed. These scenarios are intended to represent: 
1. a time period before extensive grazing activities and no gas-extraction activities;

2. a time period with some grazing activities and no gasextraction activities;

3. a time period with current land-use conditions and no gasextraction activities; and

4. a time period with current land-use conditions and increased gas-extraction activities (for example, increased gas-well pad and surface-water impoundment activities).

To quantify the changes between the current-conditions simulation and the scenario simulations, several metrics were used to quantify changes in streamflow characteristics. These metrics included average daily mean, maximum, and minimum streamflow for the calibration period (July 8, 2009-September 30, 2012); as well as average daily mean and maximum streamflow for spring flows (March, April, and May), representing a wet period; average daily mean and maximum streamflow for summer flows (July, August, and September), representing a dry period; average daily mean effective and peak bankfull streamflows; and average daily mean low-flow streamflows. The daily mean low-flow values were determined from the lowest 10th percentile of all the simulated flows. The daily mean effective and peak bankfull streamflows were those flows greater than $315 \mathrm{ft}^{3} / \mathrm{s}$ and were determined by the U.S. Department of Agriculture Natural Resources Conservation Service (Thom Garday, U.S. Department of Agriculture Natural Resources Conservation Service, written commun., 2013). The $315 \mathrm{ft}^{3} / \mathrm{s}$ cutoff serves solely as a guideline for comparing daily mean high streamflows between the current-conditions simulation and scenario simulations.

\section{Scenario 1-Simulated Time Period Before Extensive Grazing Activities and No Gas- Extraction Activities}

Scenario 1 simulated a time period before extensivegrazing activities and no gas-extraction activities; that is, conversion of all nonforested land in the watershed to forest.
All areas of anthropogenically altered land, including gas-well pads/pipelines and surface-water impoundment areas, pasture area, all gravel road area, shrub area, and urban land-use area, were converted to forest (fig. 9). The converted land use was divided into approximately 40 percent evergreen forest and approximately 60 percent deciduous forest based on General Land Office survey notes of the Ouachita Mountain region during the time of settlement (Foti and Glenn, 1990). Because mixed-forest land use contains parameters for hydrology and water quality that represent both coniferous and deciduous, it was deemed unnecessary to add in a separate mixed-forest land use. Converting the gas-well pads/ pipelines (1.4 percent), pasture (34.9 percent), gravel roads (4.1 percent), shrub ( 0.9 percent), urban ( 0.4 percent), and surface-water impoundments ( 0.2 percent) land use (fig. 3 ) to forest increased the percentage of forested land in the watershed by approximately 47 percent (from approximately 53 to approximately 100 percent) (fig. 9; table 1).

Suspended-sediment loads and volume of streamflow entering the area that comprised Brewer Lake, as simulated by the HSPF model for scenario 1, were lower than those for the current-conditions simulation. Simulated land-use changes for a time period before extensive-grazing activities and no gas-extraction activities resulted in a 13.9-percent decrease in total streamflow volume (from 113,461 acre-ft to 97,660 acre-ft) from all tributaries flowing into the area that would be encompassed by Brewer Lake, had it existed, for the calibration period (July 8, 2009-September 2012) (fig. 10). Relatedly, there was a 43.3-percent decrease (from 7,645 tons/ year to 4,336 tons/year) in suspended-sediment load for the entire simulation from all tributaries flowing into the same area (fig. 11). Additionally, average daily mean streamflow, average daily mean bankfull streamflow, average spring and summer streamflows, and average daily mean low flows (10th percentile) all decreased with increasing forested land. Average suspended-sediment loads also decreased for the same flow conditions (table 8). The decrease in streamflow volume and related streamflow metrics probably was a result of differences in increased vegetative interception of precipitation, increased infiltration with increasing forested land, and resulting decreased soil erosion. 


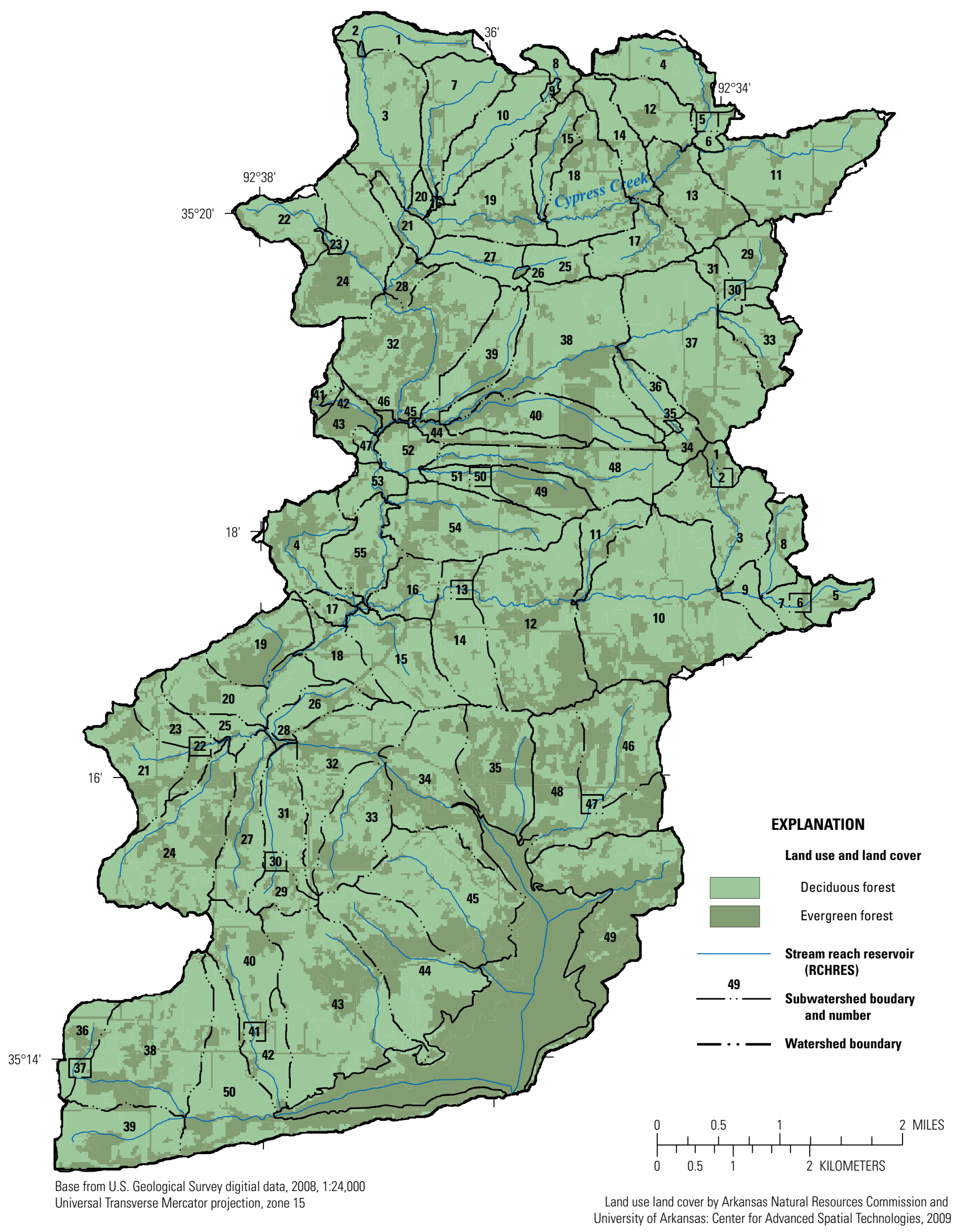

Figure 9. Land-use types used in scenario 1, a time period before extensive-grazing activities and no gas-extraction activities in the Cypress Creek watershed, Arkansas. 


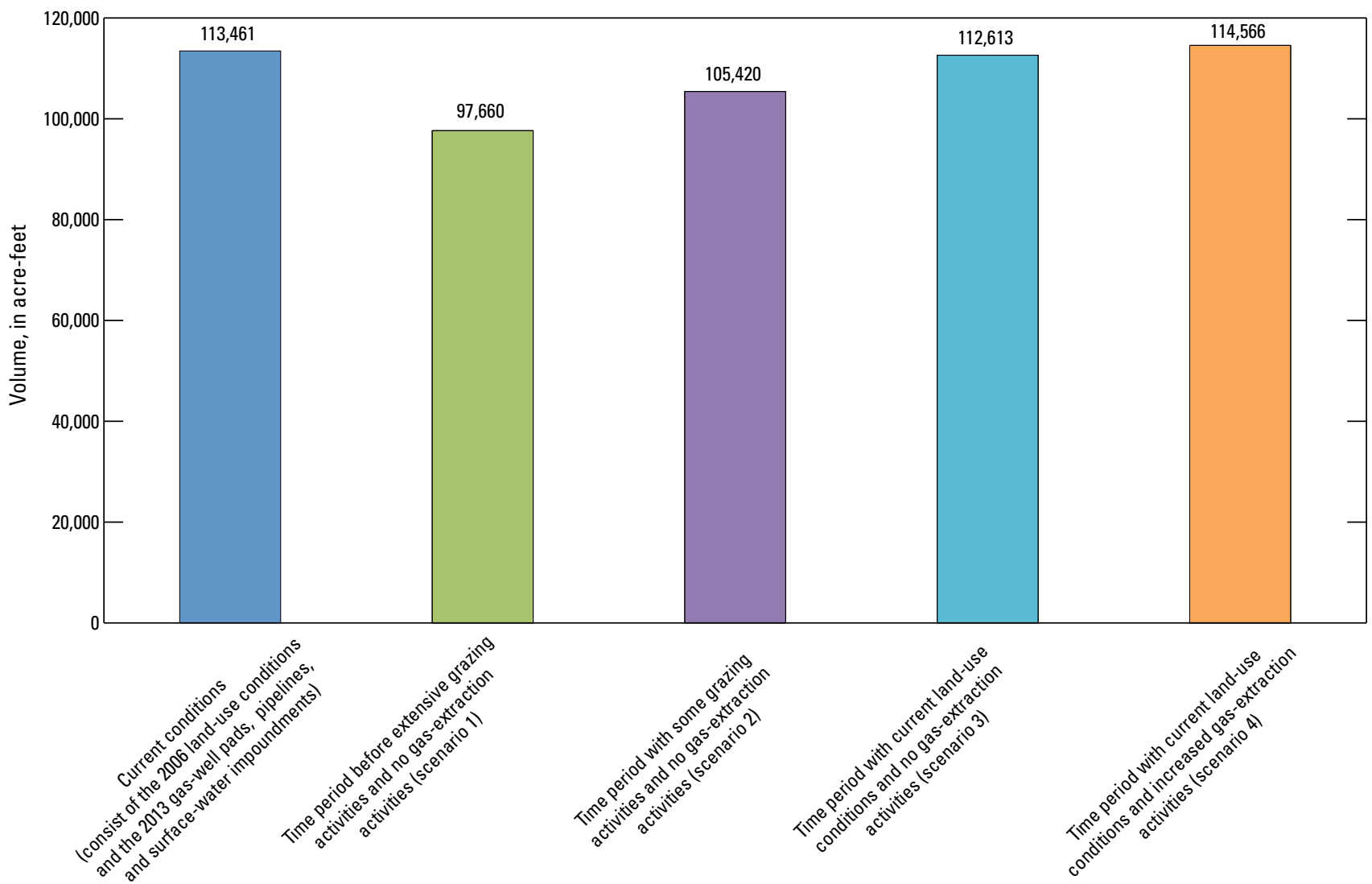

Figure 10. Comparison of total streamflow volume for the calibration period (July 8, 2009-September 2012) between the current-conditions simulation and scenario simulations for the Cypress Creek watershed. 


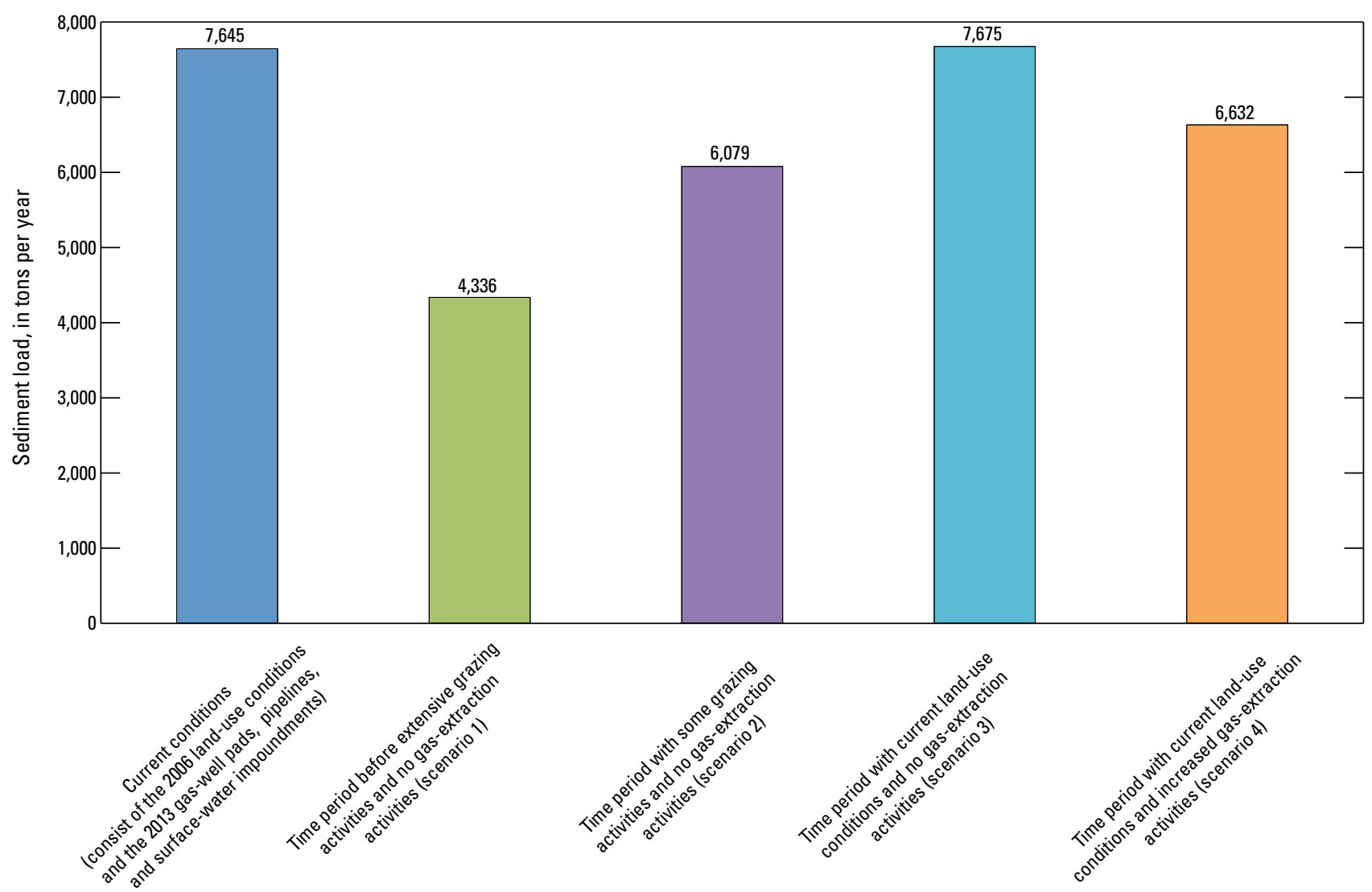

Figure 11. Comparison of yearly suspended-sediment load between the current-conditions simulation and scenario simulations for the Cypress Creek watershed. 
Table 8. Summary of July 8, 2009-September 30, 2012 simulation results for land-use change scenarios on Brewer Lake in the Cypress Creek watershed.

[Current conditions consist of the 2006 land-use conditions and the 2013 gas-well pads, pipelines, and surface-water impoundments. $\mathrm{ft}^{3} / \mathrm{s}$, cubic feet per second; mg/L, milligrams per 100 liter. The reported significant figures do not imply a level of accuracy attributed to the simulation results]

\begin{tabular}{|c|c|c|c|c|c|c|}
\hline \multirow[b]{2}{*}{ Simulated metric } & \multirow[b]{2}{*}{ Units } & \multicolumn{5}{|c|}{ Land use scenarios } \\
\hline & & $\begin{array}{c}\text { Current } \\
\text { conditions }\end{array}$ & $\begin{array}{l}\text { Time period before } \\
\text { extensive grazing } \\
\text { activities and no gas- } \\
\text { extraction activities } \\
\text { (scenario 1) }\end{array}$ & $\begin{array}{l}\text { Time period with } \\
\text { some grazing } \\
\text { activities and no gas- } \\
\text { extraction activities } \\
\text { (scenario 2) }\end{array}$ & $\begin{array}{l}\text { Time period with } \\
\text { current land-use } \\
\text { conditions and no gas- } \\
\text { extraction activities } \\
\text { (scenario } 3 \text { ) }\end{array}$ & $\begin{array}{l}\text { Time period with current } \\
\text { land-use conditions } \\
\text { and increased gas- } \\
\text { extraction activities } \\
\text { (scenario 4) }\end{array}$ \\
\hline \multicolumn{7}{|c|}{ Simulation results for all streamflows (daily mean) } \\
\hline Average streamflow & $\mathrm{ft}^{3} / \mathrm{s}$ & 48.4 & 41.7 & 45.0 & 48.1 & 48.9 \\
\hline Maximum streamflow & $\mathrm{ft}^{3} / \mathrm{s}$ & $2,019.2$ & $1,762.1$ & $1,895.6$ & $2,024.4$ & $1,927.4$ \\
\hline Minimum streamflow & $\mathrm{ft}^{3} / \mathrm{s}$ & $6.1 \times 10^{-7}$ & $3.7 \times 10^{-7}$ & $4.8 \times 10^{-7}$ & $5.9 \times 10^{-7}$ & $4.9 \times 10^{-7}$ \\
\hline Coefficient of variation & $\mathrm{ft}^{3} / \mathrm{s}$ & 3.3 & 3.4 & 3.3 & 3.3 & 3.2 \\
\hline Average sediment load & ton/day & 20.9 & 11.9 & 16.6 & 21.0 & 18.1 \\
\hline Maximum sediment load & ton/day & $4,245.2$ & $2,879.8$ & $3,723.0$ & $4,333.5$ & $3,627.3$ \\
\hline Minimum sediment load & ton/day & 0.0 & 0.0 & 0.0 & 0.0 & 0.0 \\
\hline Percentage of current condition average sediment load & percent & 100 & 56.9 & 79.4 & 100.5 & 86.6 \\
\hline \multicolumn{7}{|c|}{ Simulation results for daily mean spring streamflows (March, April, May) } \\
\hline Average streamflow & $\mathrm{ft}^{3} / \mathrm{s}$ & 70.7 & 63.0 & 66.9 & 70.3 & 70.1 \\
\hline Maximum streamflow & $\mathrm{ft}^{3} / \mathrm{s}$ & $1,628.7$ & $1,343.9$ & $1,489.1$ & $1,624.1$ & $1,608.9$ \\
\hline Average sediment load & ton/day & 37.5 & 23.4 & 31.2 & 37.8 & 32.6 \\
\hline Maximum sediment load & ton/day & $4,245.2$ & $2,879.8$ & $3,723.0$ & $4,333.5$ & $3,627.3$ \\
\hline Percentage of current condition average sediment load & percent & 100 & 62.4 & 83.2 & 100.8 & 86.9 \\
\hline \multicolumn{7}{|c|}{ Simulation results for daily mean summer streamflows (July, August, September) } \\
\hline Average streamflow & $\mathrm{ft}^{3} / \mathrm{s}$ & 30.5 & 23.6 & 26.6 & 29.4 & 32.4 \\
\hline Maximum streamflow & $\mathrm{ft}^{3} / \mathrm{s}$ & $1,823.8$ & $1,529.1$ & $1,675.7$ & $1,828.2$ & $1,724.8$ \\
\hline Average sediment load & ton/day & 16.8 & 8.8 & 12.7 & 16.8 & 14.6 \\
\hline Maximum sediment load & ton/day & $3,934.5$ & $2,184.6$ & $2,993.7$ & $3,943.2$ & $3,223.3$ \\
\hline Percentage of current condition average sediment load & percent & 100 & 52.6 & 75.6 & 100.0 & 86.9 \\
\hline \multicolumn{7}{|c|}{ Simulation results for daily mean effective and peak bankfull streamflows (greater than $315 \mathrm{ft}^{3} / \mathrm{s}$ ) } \\
\hline Number of stormflow values & days & 39 & 36 & 37 & 39 & 39 \\
\hline Percentage of time flow occurred & percent & 3.3 & 3.0 & 3.1 & 3.3 & 3.3 \\
\hline Average streamflow & $\mathrm{ft}^{3} / \mathrm{s}$ & 734.9 & 693.8 & 721.0 & 738.2 & 711.2 \\
\hline Maximum streamflow & $\mathrm{ft}^{3} / \mathrm{s}$ & $2,019.2$ & $1,762.1$ & $1,895.6$ & $2,024.4$ & $1,927.5$ \\
\hline Minimum streamflow & $\mathrm{ft}^{3} / \mathrm{s}$ & 325.8 & 320.2 & 322.7 & 320.2 & 318.7 \\
\hline Percentage of current condition average flow & percent & 100.0 & 94.4 & 98.1 & 100.4 & 96.8 \\
\hline Average sediment load & ton/day & 578.0 & 365.9 & 475.8 & 582.0 & 489.3 \\
\hline Maximum sediment load & ton/day & $4,245.2$ & $2,879.8$ & $3,723.0$ & $4,333.5$ & $3,627.3$ \\
\hline Minimum sediment load & ton/day & 1.8 & 0.2 & 0.3 & 0.3 & 1.4 \\
\hline Percentage of current condition average sediment load & percent & 100 & 63.3 & 82.3 & 100.7 & 84.7 \\
\hline
\end{tabular}


Table 8. Summary of July 8, 2009-September 30, 2012 simulation results for land-use change scenarios on Brewer Lake in the Cypress Creek watershed.-Continued [Current conditions consist of the 2006 land-use conditions and the 2013 gas-well pads, pipelines, and surface-water impoundments. $\mathrm{ft}^{3} / \mathrm{s}$, cubic feet per second; mg/L, milligrams per 100 liter. The reported significant figures do not imply a level of accuracy attributed to the simulation results]

\begin{tabular}{|c|c|c|c|c|c|c|}
\hline \multirow[b]{2}{*}{ Simulated metric } & \multirow[b]{2}{*}{ Units } & \multicolumn{5}{|c|}{ Land use scenarios } \\
\hline & & $\begin{array}{c}\text { Current } \\
\text { conditions }\end{array}$ & $\begin{array}{l}\text { Time period before } \\
\text { extensive grazing } \\
\text { activities and no gas- } \\
\text { extraction activities } \\
\text { (scenario 1) }\end{array}$ & $\begin{array}{l}\text { Time period with } \\
\text { some grazing } \\
\text { activities and no gas- } \\
\text { extraction activities } \\
\text { (scenario 2) }\end{array}$ & $\begin{array}{l}\text { Time period with } \\
\text { current land-use } \\
\text { conditions and no gas- } \\
\text { extraction activities } \\
\text { (scenario } 3 \text { ) }\end{array}$ & $\begin{array}{l}\text { Time period with current } \\
\text { land-use conditions } \\
\text { and increased gas- } \\
\text { extraction activities } \\
\text { (scenario 4) }\end{array}$ \\
\hline \multicolumn{7}{|c|}{ Simulation results for daily mean low streamflows (10th percentile) } \\
\hline Number of stormflow values & days & 118 & 118 & 118 & 118 & 118 \\
\hline Percentage of time flow occurred & percent & 10 & 10 & 10 & 10 & 10 \\
\hline Average streamflow & $\mathrm{ft}^{3} / \mathrm{s}$ & 0.03 & 0.01 & 0.02 & 0.03 & 0.03 \\
\hline Maximum streamflow & $\mathrm{ft}^{3} / \mathrm{s}$ & 0.07 & 0.05 & 0.07 & 0.07 & 0.1 \\
\hline Minimum streamflow & $\mathrm{ft}^{3} / \mathrm{s}$ & 0.0 & 0.0 & 0.0 & 0.0 & 0.0 \\
\hline Percentage of current condition average flow & percent & 100.0 & 33.3 & 66.7 & 100.0 & 100.0 \\
\hline Average sediment load & ton/day & $6.75^{\mathrm{E}-5}$ & $4.30^{\mathrm{E}-5}$ & $5.57^{\mathrm{E}-5}$ & $1.14^{\mathrm{E}-5}$ & $9.18^{\mathrm{E}-4}$ \\
\hline Maximum sediment load & ton/day & $1.46^{\mathrm{E}-3}$ & $1.42^{\mathrm{E}-3}$ & $5.51^{\mathrm{E}-3}$ & $1.27^{\mathrm{E}-3}$ & $9.46^{\mathrm{E}-3}$ \\
\hline Minimum sediment load & ton/day & 0.0 & 0.0 & 0.0 & 0.0 & $8.29^{\mathrm{E}-15}$ \\
\hline Percentage of current condition average sediment load & percent & 100 & 63.7 & 82.5 & 16.9 & $1,360.0$ \\
\hline
\end{tabular}




\section{Scenario 2-Simulated Time Period with Some Grazing Activities and No Gas-Extraction Activities}

Scenario 2 simulated a time period before any gasextraction activities but with some grazing activities; that is, simulated conversion of the current condition land use within the Cypress Creek watershed to that of 1949 land use. Single-frame aerial photography from 1949 was obtained from Earth Resources Observation and Science (EROS) Center and digitized within GIS. The quality of the aerial photography was such that only four land-use classifications could be clearly distinguished: pasture, evergreen forest, deciduous forest, and gravel roads (fig. 12). Land-use areas that were not readily identifiable from the 1949 aerial photography were compared to the current land use (2010) aerial photography provided by SWN (Southwestern Energy Co., written commun., 2011) and were classified to the closest land use from the current land use. For example, if an unidentifiable area was identified on the current aerial photography as a deciduous forest land use, then the 1949 land use was classified as deciduous forest. For the change from the 2006 to the 1949 land-use conditions, the percentage of pastureland within the watershed decreased from 34.9 percent to 22.4 percent; the percentage of evergreen forest land within the watershed increased from 19.6 percent to 39.8 percent; the percentage of deciduous forest land within the watershed increased from 28.9 percent to 36.2 percent; and the percentage of gravel roads decreased from 4.1 percent to 1.5 percent (table 1$)$.
Suspended-sediment loads and volume of streamflow entering the area that comprised Brewer Lake simulated by the HSPF model for scenario 2 were lower than those for the current-conditions simulation. Simulated land-use changes to those of the conditions in 1949 resulted in a 7.1-percent decrease in total streamflow volume (from 113,461 acre- $\mathrm{ft}$ to 105,420 acre-ft) from all tributaries flowing into the area that would be encompassed by Brewer Lake, had it existed, for the calibration period (July 8, 2009-September 30, 2012) and a 20.5-percent decrease in suspended-sediment load (from 7,645 tons/year to 6,079 tons/year) for the calibration period from all tributaries flowing into the same area (figs. 10-11). Once again, these decreases are likely a result of increased forested land, which results in greater precipitation interception by the vegetative canopy and increased infiltration because of undisturbed conditions, that is, no anthropogenically created impervious areas. Additionally, average daily mean streamflow and average spring and summer streamflows were less than streamflows associated with the 2006 land use. The average daily mean streamflow for the effective and peak bankfull streamflows decreased slightly, and the number of stormflow values (number of days streamflow exceeded $315 \mathrm{ft}^{3} / \mathrm{s}$ ) decreased from 39 days to 37 days relative to the current-conditions simulation. For scenario 2 , average suspended-sediment loads decreased for average daily mean streamflow, average daily mean low streamflow (10th percentile), and average spring and summer streamflows conditions from the current-conditions simulation (table 8). 


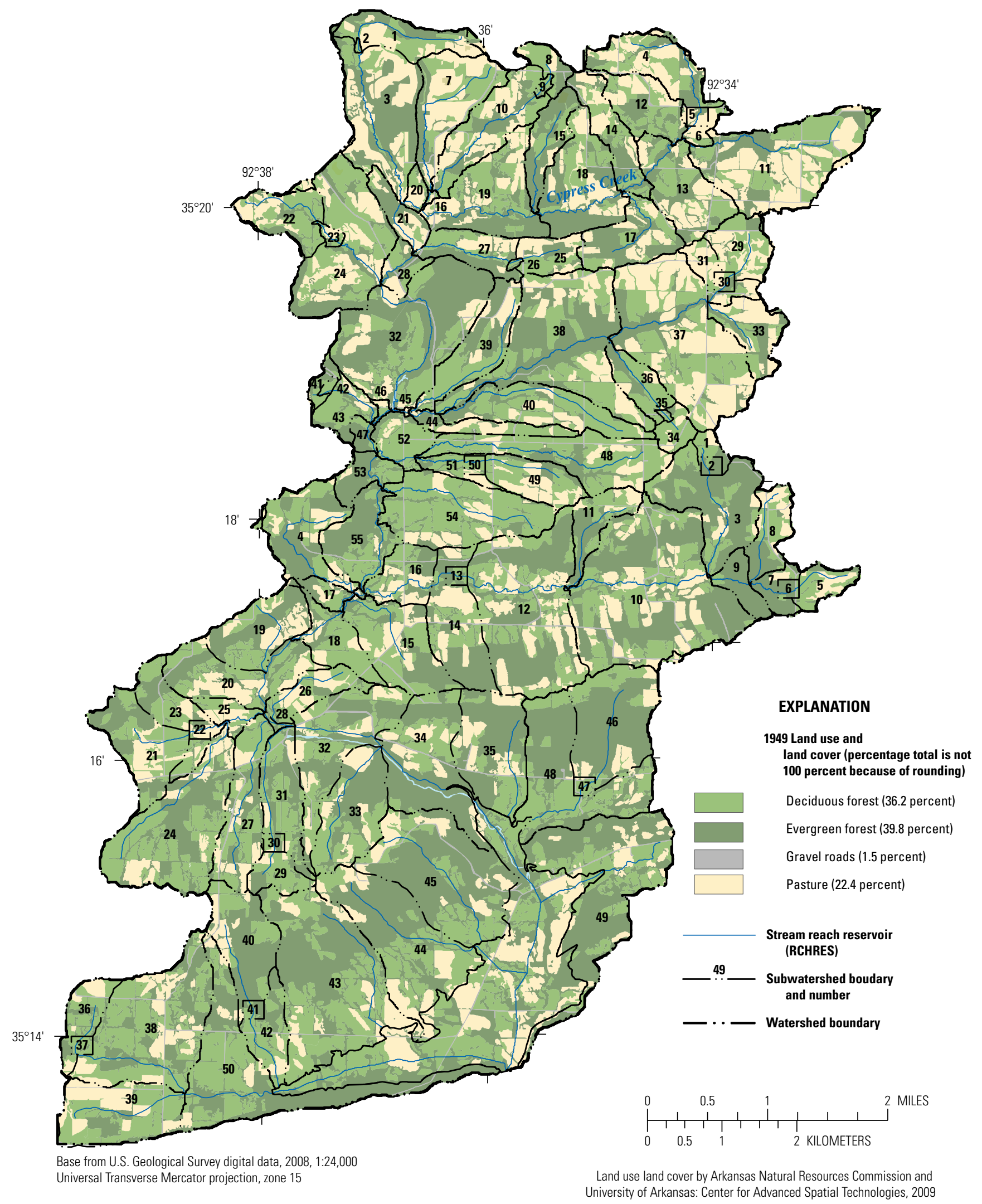

Figure 12. Land-use types used in scenario 2, a time period with some grazing but before any gas-extraction activities in the Cypress Creek watershed, Arkansas. 


\section{Scenario 3-Simulated Time Period with Current Land-Use Conditions and No Gas- Extraction Activities}

Scenario 3 simulated current conditions, but without any natural gas-pad land use or related activities; that is, simulated the Cypress Creek watershed prior to any natural gas development. This was achieved by using land use of the current-conditions simulation and removing gas-well pads/ pipelines and surface-water impoundments and associated withdrawals. The gas-well pad or surface-water impoundment land use was converted to the land use adjacent to the pad or impoundment location. For example, if the gas-well pad was located in a pasture-type land use, the gas-well pad acreage was applied to the pasture acreage (fig. 13; table 1).

Suspended-sediment loads and volume of streamflow simulated by the HSPF model for scenario 3 were mostly unchanged compared to those for the current-conditions simulation. Simulated conversion of pads and surface-water impoundments to nearby land uses resulted in a 0.7 -percent decrease in total streamflow volume (from 113,461 acre- $\mathrm{ft}$ to 112,613 acre-ft) for all tributaries flowing into Brewer Lake for the calibration period and a 0.4-percent increase in suspended-sediment load (from 7,645 tons/year to 7,675 tons/year) from all tributaries flowing into Brewer Lake (figs. 10-11). The small changes likely are a result of the small landuse change between the current-conditions simulation and current conditions, but without any natural gas-pad land use or related-activities (pipelines, surface-water impoundments, or associated gravel roads) scenario (scenario 3 ).

Although there are 35 gas-well pads/pipelines and 6 surface-water impoundments in the current-conditions simulation, the overall land use affected by the gas-well pads/pipelines is 0.5 percent of the watershed (table 1), and all of the surface-water impoundments are located on headwater streams (fig. 4). So, there is little overall effect on the volume of streamflow and suspended-sediment load within the Cypress Creek watershed for scenario 3. Except for an increase in the effective and peak bankfull streamflows for scenario 3, all other average daily mean streamflows were slightly less than or equal to values for the currentconditions simulation. Except for the average daily mean low streamflows (10th percentile), average daily mean suspended-sediment loads for the simulated time period with current land-use conditions and no gas-extraction activities scenario were slightly more or equal to the current-conditions simulation values (table 8). 


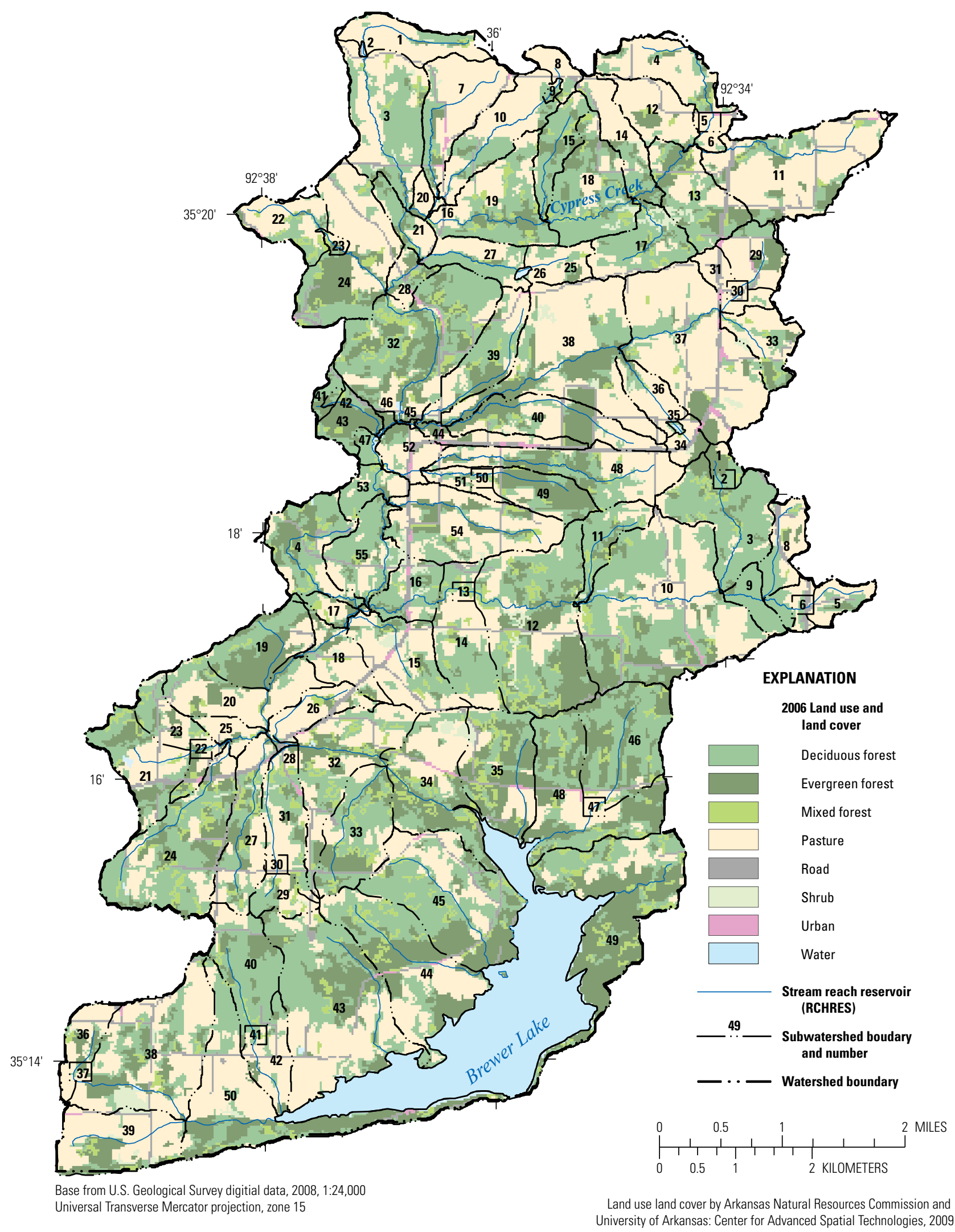

Figure 13. Land-use types used in scenario 3, a time period with current conditions but without any gas-extraction activities in the Cypress Creek watershed, Arkansas. 


\section{Scenario 4-Simulated Time Period with Current Land-Use Conditions and Increased Gas-Extraction Activities}

Scenario 4 simulated potential future conditions of increased gas-well pad and surface-water impoundment activities; that is, simulated conversion of parts of the Cypress Creek watershed to include additional gas-well pads/ pipelines and additional surface-water impoundments and associated withdrawals (more pads, pipelines, and surfacewater impoundments and associated withdrawals than in the current-conditions simulation) to represent a possible natural gas full-development condition for the area. A total of 98 large gas-well pads ( 8 acres per pad) were added to the Cypress Creek watershed (fig. 14) based on infrastructure design that gas-well pads generally are placed at a density of approximately 3 pads per section (Southwestern Energy Co., written commun., 2013) for a total of 133 gas-well pads for the scenario (35 in the current-conditions simulation). Additionally, an approximate 475 acres ( 30 percent of the total gas-well pad land use) were also added to the gas-well pad land use to account for an increase in gas pipelines within the Cypress Creek watershed; furthermore, an additional 66 acres were added to the gravel roads land use to account for increased gravel road acreage associated with increased gas activities (table 1). The additional 66 acres consist of the relatively short gravel roads connecting the gas pads to the already existing gravel roads. A total of 11 additional surface-water impoundments were placed within the Cypress Creek watershed (fig. 14) based on typical infrastructure design that water is not generally piped beyond a 3-mi radius (Southwestern Energy Co., written commun., 2011). The scenario surface-water impoundments are approximately 8 acres each and with characteristics that are based on the current-conditions simulation surface-water impoundment that comprises RCHRES 42 (table 2). This particular RCHRES was selected to best represent a "typical" surface-water impoundment within the model. The percentage of upstream land affected by the addition of scenario surface-water impoundments within the Cypress Creek watershed was 17.5 percent of the total land area.

Water-withdrawal assumptions used for the currentconditions simulation also were used for scenario 4 with modifications for potential future conditions of increased gas-well pad and surface-water impoundment activities. Water was withdrawn from the surface-water impoundments at the same rate as that of the current-conditions simulation; however, the water was withdrawn from ponds three times per year instead of two as was the case for the current-conditions simulation (see, "Hydrologic Simulation Program-FORTRAN Model Calibration" section). The additional 11 surface-water impoundments used for scenario 4 were given the withdrawal rate equal to that of RCHRES 42's withdrawal rate (table 2); again, withdrawal occurred three times per year. Additionally, water was withdrawn from Cypress Creek for 14 consecutive days, three times per year, at the same four locations as in the current-conditions simulation and at the same rate $\left(1.39 \mathrm{ft}^{3} / \mathrm{s}\right)$.

Suspended-sediment loading rates simulated by the HSPF model for scenario 4 were lower than those for the current-conditions simulation; however, streamflow volume was higher for scenario 4 than for the current-conditions simulation. Simulated land-use changes with increased gaswell pads/pipelines and surface-water impoundments resulted in a 1.0-percent increase in total volume of streamflow (from 113,461 acre-ft to 114,566 acre-ft) from all tributaries flowing into Brewer Lake for the calibration period (July 8, 2009-September 30,2012) and a 13.3-percent decrease in suspended-sediment load (from 7,645 tons/year to 6,632 tons/ year) for the calibration period from all tributaries flowing into Brewer Lake (figs. 10-11). Even though there was a slight increase in volume of streamflow within the Cypress Creek watershed, there was a relatively large decrease in suspended-sediment load entering the lake. The small increase in volume of streamflow is largely because of the increase in impervious land-use area associated with the increase of gas-well pad land use. Additionally, impoundment watertrapping efficiency increased with the increase in number of surface-water impoundments. The average daily mean streamflows and summer streamflows increased; however, average daily mean effective and peak bankfull streamflows (greater than $315 \mathrm{ft}^{3} / \mathrm{s}$ ) decreased and average daily mean low streamflows (10th percentile) remained unchanged. Because peak flows decreased, the suspended-sediment carrying capacity of the streams also decreased during peak flow. Though, average daily mean low streamflows (10th percentile) remained unchanged, maximum low streamflows increased; suspended-sediment load during low streamflow conditions also increased. However, the increase in suspendedsediment loads during low streamflows was not enough to offset decreases during times of higher streamflow yielding a 13.3-percent decrease in overall suspended-sediment load entering Brewer Lake. Average daily mean suspendedsediment load, average daily mean spring suspended-sediment load, average daily mean summer suspended-sediment load, and average daily mean effective and peak bankfull suspended-sediment load all decreased between the currentconditions simulation and the simulation of potential future conditions of increased gas-well pad and surface-water impoundment activities (table 8). 


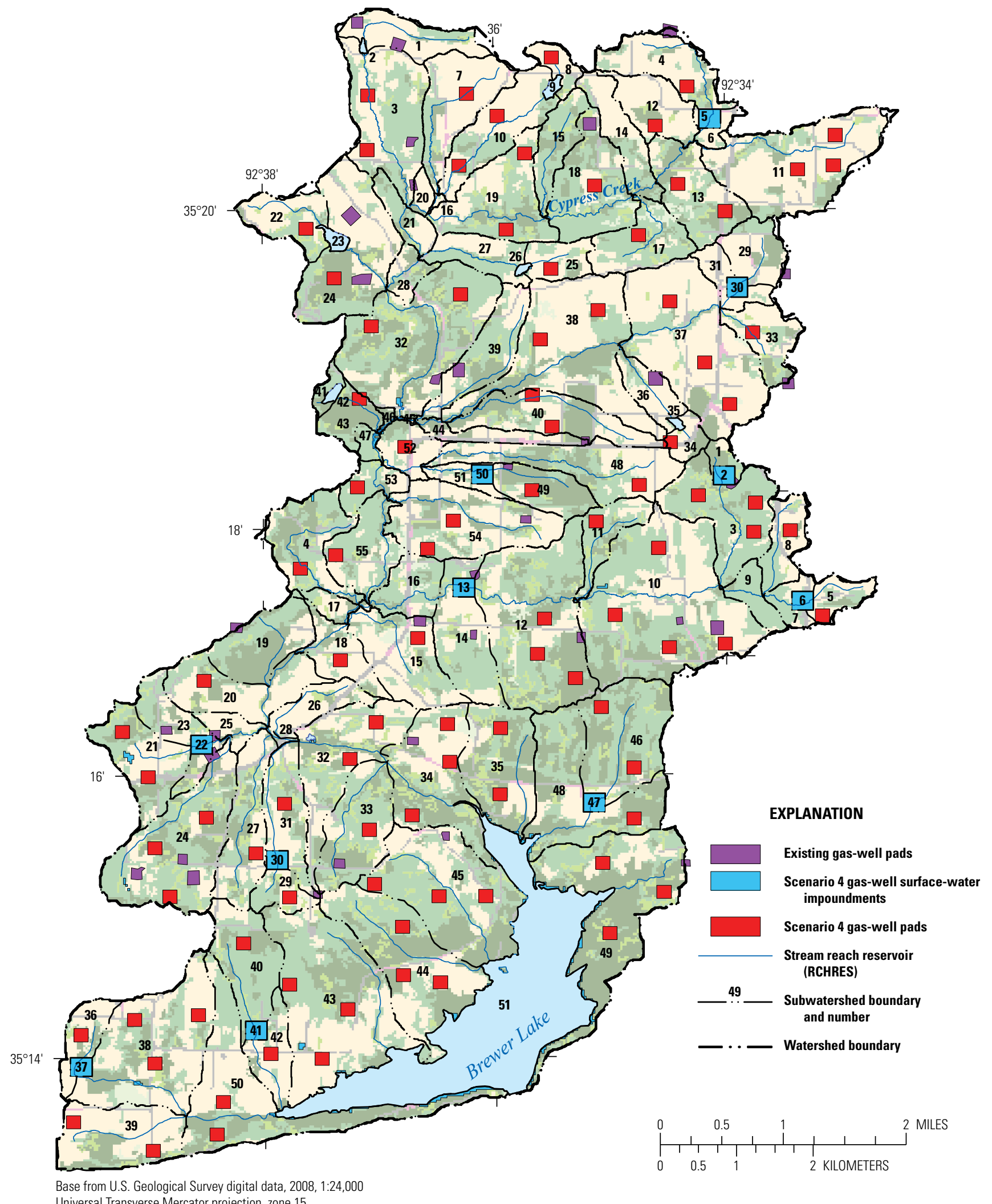

Figure 14. Potential future conditions of increased gas-extraction activities for scenario 4 in the Cypress Creek watershed, Arkansas. 
Although there were an additional 11 surface-water impoundments added to scenario 4 , most were placed at headwaters of small tributaries, upstream from most of the scenario pads (fig. 14). Though suspended sediment from gas-well pads was captured by these surface-water impoundments, the primary cause of decreased suspended sediment is attributed to one surface-water impoundment in particular, located in the central part of the watershed (fig. 14, subbasin 13). This particular surface-water impoundment captures the streamflow and suspended sediment from 11 subbasins (totaling approximately 2,482 acres) and 13 of the additional gas-well pads. Removing this surfacewater impoundment caused the average sediment load for the calibration period (July 8, 2009-September 30, 2012) to increase from 18.1 tons/day to 20.2 tons/day; the currentconditions simulation average sediment load was 20.9 tons/ day (table 8). Additionally, the largest change in streamflow with the removal of the centrally located surface-water impoundment occurred for the daily mean low streamflow (10th percentile). The maximum daily mean low streamflow decreased from $0.1 \mathrm{ft}^{3} / \mathrm{s}$ with the surface-water impoundment to $0.08 \mathrm{ft}^{3} / \mathrm{s}$ without the surface-water impoundment; the current-conditions simulation maximum daily mean low streamflow was $0.07 \mathrm{ft}^{3} / \mathrm{s}$ (table 8 ).

\section{Implications of the Four Scenarios Modeled for the Cypress Creek Watershed}

The addition of gas-well pads/pipelines has been shown to have an effect on suspended sediment only immediately after construction; sedimentation will naturally decline as the site around the gas-well pad becomes revegetated and the readily available sediment supply diminishes (Williams and others, 2008). Within the Cypress Creek watershed, the overall area affected by the land-use change for the addition of gas-well pads/pipelines and associated gravel roads (approximately 1,315 acres out of approximately 22,859 acres for scenario 4 ) is relatively minimal. The construction of additional surface-water impoundments also has varying effects on the hydrology of the system. The addition of surface-water impoundments within the Cypress Creek watershed caused the peak stormflow magnitude to decrease and summer low flows to increase, albeit, ever so slightly. Additionally, surface-water impoundments within the watershed tend to trap much of the surface-erosion sediment from various land-use activities. Although the model does not capture sediment loading or hydrologic effects at small, localized scales, a large source of sediment loading within the Cypress Creek watershed is potentially from agricultural and gravel road sources.
Graphical representations of the various scenario outcomes reflect the effects of land-use changes on streamflow volume and suspended-sediment load for the Cypress Creek watershed (figs. 10-11). Dominant changes in land use prior to any natural gas development were primarily related to clearing of land because of growing pastoral activity (scenario 2). Scenario 1 (a completely forested scenario) resulted in a streamflow volume of 97,660 acre-ft of water, additional land clearing predominantly for pastoral purposes (scenario 2), resulted in a streamflow volume of 105,420 acre-ft, an increase of 7.9 percent relative to scenario 1 . The removal of existing gas-well pads/pipelines and surface-water impoundments from the current conditions scenario for the scenario 3 simulation resulted in a decrease of 848 acre- $\mathrm{ft}$ of streamflow volume, or a decrease of 0.7 percent. As mentioned above, surface-water impoundments tend to trap much of the surface-erosion sediment from various land-use activities in the watershed. Although suspended sediment was noted to increase with the transition from scenario 1 (completely forested) to scenario 3 (current conditions without natural-gas activities) by an increase of 3,339 tons/year (77.0 percent), the surface-water impoundments (scenario 4 ) resulted in an overall decrease in suspended-sediment load (from 7,675 tons/ year for scenario 3 to 6,632 tons/year of suspended sediment for scenario 4, a 13.6-percent decrease in suspended sediment) even with additional gas-well pads/pipelines. The modeled scenario for projected increase in gas-well pad/pipelines and surface-water impoundments had little overall effect on streamflow volume. However, it is possible for there to be areas where suspended-sediment loading increased, but these increases may not be apparent because of the model scale and approach. For example, suspended-sediment loads could increase immediately downstream from gravel roads, gas-well pads, or pipeline crossings.

Changes in water quality also can occur with the changes in flow regime. For larger surface-water impoundments, Batalla and others (2004) have shown that altered flows can influence oxygen concentrations, temperature, suspended solids, and cycling of organic matter and other nutrients, as well as having direct impacts on biota. Furthermore, the surface-water impoundments act as traps for additional suspended sediment and sediment-associated constituents that would otherwise be transported downstream (Foster and others, 2012).

Because of the high sediment-loading rates associated with gravel roads and the large amount of pasture within the watershed (tables 1 and 5), the factors most responsible for most of the suspended sediment within the Cypress Creek watershed are likely associated more with the pastureland and gravel roads, than factors associated with gas-well pads/ pipelines. Compared to forest land use, ratios of gully erosion to sheet erosion are higher in areas of agricultural land use (Missouri Department of Conservation, 2013). Furthermore, gravel roads can be a primary source of suspended sediment in 
a wide range of forested areas, and in a land use where natural erosion rates tend to be very slow, gravel roads in forested land have higher erosion rates and disrupt geomorphologic and hydrologic processes (Ramos-Scharrón and MacDonald, 2005). Within the Cypress Creek watershed, the amount of land disturbed for the simulated potential future conditions of increased gas-well pad and surface water-impoundment activities was minimal, and the resulting effects were also minimal, based on the parameters and assumptions used in the HSPF model. The addition of gas-well pads/pipelines and associated gravel road for scenario 4 resulted in 6.9 percent of the total land area being disturbed. However, most of this "disturbed" 6.9 percent area was converted from the already "disturbed" pastureland use. The Arkansas Natural Resources Commission (2013) and the Arkansas Department of Environmental Quality (2008) list sediment from "poor pastures" as a primary concern related to nonpoint-source pollution in north-central Arkansas, and unpaved roads are another major source of sediment. The initial Nonpoint Source Pollution Assessment for Arkansas together with updates in 1990 and again in 1997 indicated agricultural activities as a major source of waterbody impairment (for sediment) in the State (Arkansas Department of Environmental Quality, 2008). In Arkansas, approximately 88 percent of rural roads are unpaved (Arkansas Department of Environmental Quality, 2008). Because of these major sources of suspended sediment and resultant changes in streamflow from cleared land, conversion of land associated with these particular types of land use suggests that, in regards to suspended sediment, gravel roads and pasture may be of equal or greater concern than construction of gas-well pads/pipelines for the Cypress Creek watershed.

\section{Summary}

Cypress Creek is located in central Arkansas and is the main tributary to Brewer Lake, which serves as the primary water supply for Conway, Arkansas. A model of the Cypress Creek watershed was developed and calibrated in cooperation with Southwestern Energy Company using detailed precipitation, streamflow, and discrete suspended-sediment data collected from 2009 through 2012. These data were used in conjunction with the Hydrologic Simulation ProgramFORTRAN model to address different potential gas-extraction activities within the Cypress Creek watershed.

The calibrated Hydrologic Simulation ProgramFORTRAN model was used to simulate four land-use scenarios and examine the potential effects of these land-use changes on suspended sediment within the Cypress Creek watershed. These simulated scenarios included (1) the conversion of all nonforested land to forest, representing a time period before extensive grazing activities and no gasextraction activities; (2) a land-use change to that of 1949, representing a time period with some grazing activities and no gas-extraction activities; (3) a time period with current land-use conditions but without any gas-extraction activities, that is, the exclusion of gas-well pads/pipelines, associated gravel roads, and surface-water impoundments; and (4) a time period with current land-use condition but with increased gas-extraction activities to include an increased number of gas-well pads (from 35 in the current-conditions simulation to 133 for scenario 4), pipelines, and surface-water impoundment activities (from 6 in the current-conditions simulation to 17 for scenario 4) to represent a possible future natural gas fulldevelopment condition for the Cypress Creek watershed.

The current conditions-simulation within the Cypress Creek watershed used the 2006 land use, which consisted primarily of forest and pasture, as well as the current (2012) 35 gas-well pads/pipelines and 6 large gas-well surface-water impoundments that compose approximately 1.6 percent of the land use. Simulating a time period before extensive-grazing activities and no gas-extraction activities for scenario 1 resulted in a decrease in suspended-sediment loads and volume of streamflow within the Cypress Creek watershed, compared to the current-conditions simulation. Simulating a time period before any gas-extraction activities but with some grazing activities for scenario 2 also resulted in a decrease in suspended-sediment loads and volume of streamflow within the Cypress Creek watershed compared to the current-conditions simulation. These decreases are likely a result of increased forested land, which results in greater precipitation interception by the vegetative canopy and increased infiltration because of undisturbed conditions, that is, no anthropogenically created impervious areas. Simulating current conditions, but without any natural gas-well pad land use or related activities for scenario 3, resulted in mostly unchanged suspended-sediment loads and volume of streamflow within the Cypress Creek watershed, as compared to the current-conditions simulation. The overall land use affected by the gas-well pads and pipelines for the current-conditions scenario is 0.5 percent of the watershed, and all of the surface-water impoundments are located on headwater streams, so there is little overall effect on the volume of streamflow and suspended-sediment load within the Cypress Creek watershed when these features are removed for scenario 3. Finally, simulating potential future conditions of increased gas-well pad and surface-water impoundment activities for scenario 4 resulted in a decrease in suspendedsediment loads and a slight increase of volume of streamflow within the Cypress Creek watershed. The small increase in volume of streamflow is largely because of the increase in impervious land-use area associated with the increase of gaswell pad land use. Even though there was a slight increase in volume of streamflow within the Cypress Creek watershed, there was a relatively large decrease in suspended-sediment load entering the lake. The decrease in suspended-sediment loads was because of an increase in the water-trapping efficiency with the increase in number of surface-water 
impoundments. However, the calibrated Hydrologic Simulation Program - FORTRAN model does not capture effects at small, localized scales, for example, the sediment load in a stream immediately downstream from a gravel road, gas-well pad, or pipeline crossing.

The Arkansas Natural Resources Commission and the Arkansas Department of Environmental Quality list sediment from "poor pastures" as a primary concern related to nonpoint-source pollution in north-central Arkansas. The initial Nonpoint Source Pollution Assessment for Arkansas lists agricultural activities as a major source of waterbody impairment (for sediment) in the State. Other sources of surface erosion are unpaved roads, in which the main constituent is sediment. Because of the high sediment-loading rates associated with gravel roads and the large amount of pasture within the watershed, the factors most responsible for suspended sediment within the Cypress Creek watershed are likely associated more with the pastureland and gravel roads, than factors associated with gas-well pads/pipelines.

\section{References}

Al-Abed, N.A., and Whiteley, H.R., 2002, Calibration of the Hydrologic Simulation Program Fortran (HSPF) model using automatic calibration and geographical information systems: Hydrological Processes, v. 16, p. 3169-3188.

Arkansas Department of Environmental Quality, 2008, Integrated monitoring and assessment report: Arkansas Department of Environmental Quality, variously paginated.

Arkansas Geological Survey, 2012, Stratigraphic summary of the Arkansas River Valley and Ouachita Mountains: Arkansas Geological Survey, accessed October 19, 2012, at http://www.geology.ar.gov/geology/strat_arkvalley_ ouachita.htm.

Arkansas Natural Resources Commission and University of Arkansas: Center for Advanced Spatial Technologies, 2009, 2006 Arkansas land use/land cover, accessed March 13, 2009, at http://www.cast.uark.edu/home/research/geomatics/ remote-sensing/arkansas-land-useland-cover.html.

Arkansas Natural Resources Commission, 2013, Nonpoint source pollution management program: accessed February 25, 2013, at http://anrc.ark.org/divisions/water-resourcesmanagement/nonpoint-pollution/.

Batalla, J.R., Gomez, C.M., and Kondolf, G.M., 2004, Reservoir-induced hydrological changes in the Ebro River Basin (NE Spain): Journal of Hydrology, v. 290, p. 117-136.
Bicknell, B.R., Imhoff, J.C., Kittle, J.L., Jr., Jobes, T.H., Donigian, A.S., Jr., 2001, Hydrologic Simulation ProgramFORTRAN, user's manual for version 12: Research Triangle Park, N.C., U.S. Environmental Protection Agency, National Exposure Research Laboratory, Office of Research and Development, $845 \mathrm{p}$.

Brenton, R.W., and Arnett, T.L., 1993, Methods of analysis by the U.S. Geological Survey National Water Quality Laboratory; determination of dissolved organic carbon by UV-promoted persulfate oxidation and infrared spectrometry: U.S. Geological Survey Open-File Report 92-480, 12 p.

Bureau of Land Management, 2006, Resource management plan amendment and environmental impact statement, Glenwood Springs Field Office, Roan Plateau Planning Area: Department of the Interior, Bureau of Land Management, variously paginated.

Childress, C.J.O., Foreman, W.T., Conner, B.F., and Maloney, T.J., 1999, New reporting procedures based on longterm method detection levels and some considerations of water-quality data provided by the U.S. Geological Survey National Water Quality Laboratory: U.S. Geological Survey Open-File Report 99-193, 19 p.

Cohn, T.A., 1988, Adjusted maximum likelihood estimation of the moments of lognormal populations from type 1 censored samples: U.S. Geological Survey Open-File Report 88-350, $34 \mathrm{p}$.

Cohn, T.A., DeLong, L.L., Gilroy, E.J., Hirsch, R.M., and Wells, D.K., 1989, Estimating constituent loads: Water Resources Research, v. 2, no. 5, p. 937-942.

Cohn, T.A., Gilroy, E.J., and Baier, W.G., 1992, Estimating fluvial transport of trace constituents using a regression model with data subject to censoring: Proceedings of the Joint Statistical Meeting, Boston, Mass., August 9-13, 1992, p. 142-151.

Conway Corporation, 2012, James H. Brewer Lake, accessed October 16, 2012, at http://www.conwaycorp.com/About/ History/BrewerLake.aspx.

Crawford, C.G., 1991, Estimation of suspended-sediment rating curves and mean suspended-sediment loads: Journal of Hydrology, v. 129, p. 331-348.

Dempster, A.P., Laird, N.M., and Rubin, D.B., 1977, Maximum likelihood from incomplete data via the EM algorithm: Journal of the Royal Statistical Society, series B, v. 39 , no. 1 , p. 1-38. 
Donigian, A.S., Jr., 2000, HSPF training workshop handbook and $C D$, lecture \#19-Calibration and verification issues, slide \#L19-22: Environmental Protection Agency Headquarters, Washington Information Center, January, 10-14, 2000, presented and prepared for U.S. EPA, Office of Water, Office of Science and Technology, Washington, D.C.

Donigian, A.S., Jr., and Crawford, N.H., 1977, Simulation of nutrient loadings in surface runoff with the NPS model: U.S. Environmental Protection Agency Ecological Research Series EPA-600/3-77-065, 110 p.

Donigian, A.S., Jr., and Davis, H.H., 1978, User's manual for Agricultural Runoff Management (ARM) model: U.S. Environmental Protection Agency Report EPA-600/3-78$080,163 \mathrm{p}$.

Donigian, A.S., Jr., Imhoff, J.C., Bicknell, B.R., and Kittle, J.L., Jr., 1984, Application guide for Hydrological Simulation Program-FORTRAN (HSPF): Environmental Protection Agency Environmental Research Laboratory, EPA-600/3-84-065, 177 p.

Donigian, A.S., Jr., and Love, J.T., 2003, Sediment calibration procedures and guidelines for watershed modeling: Chicago, Illinois, WEF TMDL 2003, November 16-19, 2003.

Edwards, T.K., and Glysson, G.D., 1999, Field methods for measurement of fluvial sediment: U.S. Geological Survey Techniques of Water-Resources Investigations, book 3, chap. C2, 89 p.

Fenneman, N.M., and Johnson, D.W., 1946, Physical divisions of the United States (map): Washington, D.C., U.S. Geological Survey.

Fishman, M.J., ed., 1993, Field methods of analysis by the U.S. Geological Survey National Water Quality Laboratory; determination of inorganic and organic constituents in water and fluvial sediments: U.S. Geological Survey Open-File Report 93-125, 217 p.

Foster, G.M., Lee, C.J., and Ziegler, A.C., 2012, Sediment transport to and from small impoundments in northeast Kansas, March 2009 through September 2011: U.S. Geological Survey Scientific Investigations Report 20125269, 38 p.

Foti, T.L., and Glenn, S.M., 1990, The Ouachita Mountain landscape at the time of settlement: Morrilton, Arkansas, Winrock International, Conference on Restoring Old Growth Forests in the Interior Highlands of Arkansas and Oklahoma, September 19-20, 1990.
Gilroy, E.J., Hirsch, R.M., and Cohn, T.A., 1990, Mean square error of regression-based constituent transport estimates: Water Resources Research, v. 26, no. 9, p. 2069-2077.

Greene, D.G., and Hudlow, M.D., 1982, Hydrometeorologic grid mapping procedures, in Johnson, A.I., and Clark, R.A., American Water Resources Association International Symposium on Hydrometeorology, Proceedings: Denver, Colorado, June 13-17, 1982, 20 p.

Gupta, H.V., Sorooshian S., and Yapo P.O., 1999, Status of automatic calibration for hydrologic models: Comparison with multilevel expert calibration: Journal of Hydrologic Engineering, v. 4, no. 2, p. 135-143.

Guy, H.P., 1969, Laboratory theory and methods for sediment analysis: U.S. Geological Survey Techniques of WaterResources Investigations, book 5, chap. C1, 58 p.

Helsel, D.R., and Hirsch, R.M., 2002, Statistical methods in water resources: U. S. Geological Survey Techniques of Water-Resource Investigations, book 4, chap. A3, 523 p.

Hummel, P., Kittle, J., and Gray, M., 2001, WDMUtil, version 2.0 - A tool for managing watershed modeling time-series data: U.S. Environmental Protection Agency Contract No. 68-C-98-010, 157 p.

Likes, Jiri, 1980, Variance of the MVUE for lognormal variance: Technometrics, v. 22, no. 2, p. 253-258.

Maryland Department of the Environment, 2006, Maryland's 2006 TMDL implementation guidance for local governments: Baltimore, Maryland, The Maryland Department of the Environment, accessed February 20, 2013, at http://www.mde.state.md.us/programs/Water/ TMDL/TMDLImplementation/Documents/www.mde.state. md.us/assets/document/final_TMDL_Implementation_ Guidance_for_LG.pdf.

Missouri Department of Conservation, 2013, Water quality: mdconline, accessed February 21, 2013, at http://mdc. mo.gov/landwater-care/stream-and-watershed-management/ missouri-watersheds/south-grand-river/water-quality.

Moore, Keara, and Mohamoud, Yusuf, 2007, Two automated methods for creating hydraulic function tables (FTABLES): U.S. Environmental Protection Agency BASINS Technical Note 2, $14 \mathrm{p}$.

Moriasi, D.N., Arnold, J.G., VanLiew, M.W., Bingner, R.L., Hrmel, R.D., and Veith, T.L., 2007, Model evaluation guidelines for systematic quantification of accuracy in watershed simulations: American Society of Agricultural and Biological Engineers, v. 50, no. 3, p. 885-900. 
National Oceanic and Atmospheric Administration, 2002, About the stage III data: Distributed Model Intercomparison Project, accessed January 26, 2012, at http://www.nws.noaa. gov/oh/hrl/dmip/stageiii_info.htm.

National Oceanic and Atmospheric Administration, 2008, Archive of River Forecast Center operational NEXRAD data: NOAA Hydrologic Data System Group, accessed January 26, 2012, at http://dipper.nws.noaa.gov/hdsb/data/ nexrad/nexrad.html.

National Oceanic and Atmospheric Administration, 2010, ABRFC precipitation processing: National Weather Service River Forecast Center: accessed January 26, 2012, at http:// www.srh.noaa.gov/abrfc/?n=pcpn_methods.

National Oceanic and Atmospheric Administration, 2012a, Climate data online: NOAA National Climatic Data Center, accessed July 26, 2012, at http://www.ncdc.noaa.gov/cdoweb/.

National Oceanic and Atmospheric Administration, 2012b, Multi-sensor precipitation reanalysis: National Climatic Data Center, accessed January 26, 2012, at http://www.ncdc. noaa.gov/oa/rsad/mpr.html.

Ockerman, D.J., and Heitmuller, F.T., 2010, Simulation of streamflow and suspended-sediment concentrations and loads in the lower Nueces River watershed, downstream from Lake Corpus Christi to the Nueces Estuary, South Texas, 1958-2008: U.S. Geological Survey Scientific Investigations Report 2010-5194, $50 \mathrm{p}$.

Ockerman, D.J., and Roussel, M.C., 2009, Simulation of streamflow and water quality in the Leon Creek watershed, Bexar County, Texas, 1997-2004: U.S. Geological Survey Scientific Investigations Report 2009-5191, 50 p.

Ramos-Scharrón, C.E., and MacDonald, L.H., 2005, Measurement and prediction of sediment production from unpaved roads, St. John, US Virgin Islands: Earth Surface Processes and Landforms v. 30, p. 1283-1304.

Rantz, S.E., and others, 1982, Measurement and computation of streamflow-Volume 1, Measurement of stage and discharge: U.S. Geological Survey Water-Supply Paper 2175, $284 \mathrm{p}$.

Runkel, R.L., Crawford, C.G., and Cohn, T.A., 2004, Load estimator (LOADEST) - A FORTRAN program for estimating constituent loads in streams and rivers: U.S. Geological Survey Techniques and Methods, book 4, chap. A5, accessed July 2010, at http://pubs.er.usgs.gov/usgspubs/ $\mathrm{tm} / \mathrm{tm} 4 \mathrm{~A} 5$.
Ryu, J.H., 2009, Application of HSPF to the distributed model intercomparison project - Case study: Journal of Hydrologic Engineering, v. 14, no. 8, p. 847-857.

Scoles, S., Anderson, S. Turton, D., and Miller, E., 2001, Forestry and water quality, A review of watershed research in the Ouachita Mountains: Stillwater, Oklahoma, Oklahoma State University, Oklahoma Cooperative Extension Service, Water-Quality Series Circular E-932, $29 \mathrm{p}$.

Shedd, R.C., and Fulton, R.A., 1993, WSR-88D Precipitation processing and its use in National Weather Service hydrologic forecasting, in Engineering Hydrology, Proceedings of the Symposium, San Francisco, Calif., July 25-30, 1993: Proceedings, Hydraulics Division of the American Society of Civil Engineers.

Skahill, B.E., 2004, Use of the Hydrological Simulation Program-FORTRAN (HSPF) model for watershed studies: System-wide Modeling, Assessment, and Restoration Technologies, ERDC/TN SMART-04-1 September 2004, $26 \mathrm{p}$.

Skahill, B.E., and Doherty, J., 2006, Efficient accommodation of local minima in watershed model calibration: Journal of Hydrology, v. 329, p. 122-139.

Soong, D.T., Straub, T.D., and Murphy, E.A., 2005, Continuous hydrologic simulation and flood-frequency, hydraulic, and flood-hazard analysis of the Blackberry Creek watershed, Kane County, Illinois: U.S. Geological Survey Scientific Investigations Report 2005-5270, 66 p.

Tetra Tech, Inc., 2004, Translation of SET loading estimates to Upper Neuse performance targets: Research Triangle Park, N.C., Tetra Tech, Inc., Memorandum dated February 19, 2004.

U.S. Army Corps of Engineers, 1994, Flood-runoff analysis: U.S. Army Corps of Engineers Engineering Manual, EM 1110-2-1417, 214 p.

U.S. Army Corps of Engineers, 2002, Conway water supply study city of Conway, Arkansas: Section 22, Water Resource Development Act of 1974, July 2002, 35 p.

U.S. Department of Agriculture, 2012a, Official soil series descriptions: USDA-NRCS Soil Survey Division, accessed on September 4, 2012, at https://soilseries.sc.egov.usda.gov/ osdlist.asp.

U.S. Department of Agriculture, 2012b, Soil Survey Geographic (SSURGO) database: National Resources Conservation Service, accessed February 1, 2012, at http:// datagateway.nrcs.usda.gov/GDGOrder.aspx. 
U.S. Environmental Protection Agency, 1999, Preliminary data summary of urban stormwater best management practices: Office of Water EPA-821-R-99-012.

U.S. Environmental Protection Agency, 2003, BASINS (Better Assessment Science Integrating Point and Nonpoint sources), accessed March 28, 2009, at http://www.epa.gov/ waterscience/basins/.

U.S. Geological Survey, 2011, National elevation dataset, accessed November 4, 2011, at http://ned.usgs.gov/.

U.S. Geological Survey, 2012a, National hydrogaphy dataset, accessed September 4, 2012, at http://nhd.usgs.gov/.

U.S. Geological Survey, 2012b, USGS water data for the Nation, accessed November 27, 2012, at http://waterdata. usgs.gov/nwis.

U.S. Geological Survey, variously dated, National field manual for the collection of water-quality data: U.S. Geological Survey Techniques of Water-Resources Investigations, book 9, chaps. A1-A9, available online at http://pubs.water. usgs.gov/twri9A.

Wershaw, R.L., Fishman, M.J., Grabbe, R.R., and Lowe, L.E., eds., 1987, Methods for the determination of organic substances in water and fluvial sediments: U.S. Geological Survey Techniques of Water-Resources Investigations, book 5, chap. A3, 80 p.

Wilde, F.D., and Radke, D.B., 1998, Field measurements: U.S. Geological Survey Techniques of Water-Resources Investigations, book 9, chap. A6, variously paginated.
Wilde, F.D., Radke, D.B., Gibs, Jacob, Iwatsubo, R.T., 1998a, Preparations for water sampling: U.S. Geological Survey Techniques of Water-Resources Investigations, book 9, chap. A1, variously paginated.

Wilde, F.D., Radke, D.B., Gibs, Jacob, Iwatsubo, R.T., 1998b, Selection of equipment for water sampling: U.S. Geological Survey Techniques of Water-Resources Investigations, book 9 , chap. A2, variously paginated.

Wilde, F.D., Radke, D.B., Gibs, Jacob, Iwatsubo, R.T., 1998c, Cleaning of equipment for water sampling: U.S. Geological Survey Techniques of Water-Resources Investigations, book 9 , chap. A3, variously paginated.

Wilde, F.D., Radke, D.B., Gibs, Jacob, Iwatsubo, R.T., 1999a, Collection of water samples: U.S. Geological Survey Techniques of Water-Resources Investigations, book 9, chap. A4, variously paginated.

Wilde, F.D., Radke, D.B., Gibs, Jacob, Iwatsubo, R.T., 1999b, Processing of water samples: U.S. Geological Survey Techniques of Water-Resources Investigations, book 9, chap. A5, variously paginated.

Williams, H.F.L., Havens, D.L., Banks, K.E., and Wachal, D.J., 2008, Field-based monitoring of sediment runoff from natural gas well sites in Denton County, Texas, USA: Environmental Geology, v. 55, p. 1463-1471.

Wolynetz, M.S., 1979, Algorithm 139-Maximum likelihood estimation in a linear model with confined and censored data: Applied Statistics, v. 28, p. 195-206. 
Publishing support provided by the U.S. Geological Survey Publishing Network, Lafayette and Tacoma Publishing Service Centers For more information concerning the research in this report, contact the Director, Arkansas Water Science Center

U.S. Geological Survey

401 Hardin Road

Little Rock, Arkansas 72211-3528 


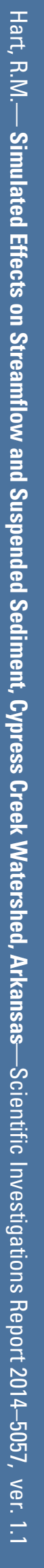

